PNNL-11696

UC-2030

\title{
Electrochemical Reduction Removal of Technetium-99 from Hanford Tank Wastes
}

\author{
W. E. Lawrence \\ D. L. Blanchard, Jr. \\ D. E. Kurath
}

September 1997

Prepared for the

U.S. Department of Energy

under Contract DE-AC06-76RLO 1830

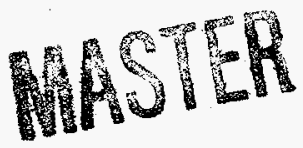

Pacific Northwest National Laboratory

Richland, Washington 99352 


\section{DISCLAIMER}

This report was prepared as an account of work sponsored by an agency of the United States Government. Neither the United States Government nor any agency thereof, nor any of their employees, make any warranty, express or implied, or ascumes any legal liability or responsibility for the accuracy, completeness, or usefulness of any information, apparatus, product, or process disclosed, or represents that its use would not infringe privately owned rights. Reference herein to any specific commercial product, process, or service by trade name, trademark, manufacturer, or otherwise does not necessarily constitute or imply its endorsement, recommendation, or favoring by the United States Government or any agency thereof. The views and opinions of authors expressed herein do not necessarily state or reflect those of the United States Government or any agency thereof. 


\section{DISCLAIMER}

Portions of this document may be illegible electronic image products. Images are produced from the best available original document. 


\section{Summary}

The removal of technetium $\left({ }^{99} \mathrm{Tc}\right)$ from Hanford tank waste supernatant liquids has been demonstrated using an electrochemical-based separation process. A potential cleanup strategy is to retrieve the waste and separate components into high-level and low-level waste fractions (Orme et al. 1996). However, some of the tanks contain technetium-99 (99Tc) at concentrations deemed to be unacceptable for ultimate processing and disposal. Conventional extraction processes have been shown to be inefficient at removal of 99Tc due to the presence of nonpertechnetate species (Blanchard et al. 1997). Electrochemical processing has been shown to oxidize the nonextractable species and subsequently separate the ${ }^{99} \mathrm{Tc}$ by electrodeposition.

The data obtained were used to support a comparison of ion exchange and electrochemical processing as removal methods. The electrochemical process has the flexibility to serve as a standalone process or to support conventional processes as a pretreatment step for the oxidation of nonextractable ${ }^{99} \mathrm{Tc}$ and/or organic decomplexation.

A separation procedure developed by AEA Technologies (AEAT) for simulated Hanford tank supernatant liquids was adapted for the actual waste studies conducted at Pacific Northwest National Laboratory (PNNL). (a) Prior to electroreduction separation of 99Tc from the supernatant liquid, an electrochemical oxidation was carried out in which nonpertechnetate or nonextractable ${ }^{99} \mathrm{Tc}$ was oxidized to more readily extractable species such as pertechnetate, and the organic content was decreased. After oxidation, an electroreduction was performed to remove the ${ }^{99} \mathrm{Tc}$ from the supernatant liquid as $\mathrm{Tc}$ or $\mathrm{TcO}_{2}$ deposited on the cathode.

Removal of $99 \mathrm{Tc}$ was demonstrated with two supernatant liquids from Tanks 241-AW-101 (AW-101) and 241-AN-107 (AN-107). Tank AW-101 waste has lower nonpertechnetate and lower organic contents than AN-107. During supernatant liquid oxidation, more than $40 \%$ of the nonpertechnetate or nonextractable ${ }^{99} \mathrm{Tc}$ present in the AW-101 waste was oxidized to an extractable form. Up to $75 \%$ of the nonextractable $99 \mathrm{Tc}$ was oxidized in the AN-107 waste.

During the oxidation of the nonextractable $99 \mathrm{Tc}$, other species such as organic compounds are also oxidized. During two of the pre-oxidation experiments, the total organic carbon content was reduced by $>90 \%$. In addition, a portion of the $90 \mathrm{Sr}$ present in the high-organic $\mathrm{AN}-107$ supernatant liquid was decomplexed, resulting in a $21 \%$ decrease of $90 \mathrm{Sr}$ present as a complex in the supernatant liquid.

Electroreduction testing showed a decontamination factor (DF) of 19 for the removal of ${ }^{99} \mathrm{Tc}$ from the AW-101 supernatant liquid. A DF up to 6.7 was obtained for AN-107. The DFs obtained exceed anticipated removal requirements of a DF of 5 . The DF for AW-101 was about a factor of 5 lower for the actual waste test than that obtained by AEAT in the simulant waste test. For AN-107 waste the DFs were comparable in both the actual waste and simulant testing.

(a) Pacific Northwest National Laboratory is operated by Battelle for the U.S. Department of Energy under Contract DE-AC06-76RLO 1830. 
This work has demonstrated successful removal of $99 \mathrm{Tc}$ using a combination of electrochemical oxidation and reduction/deposition. The amount of decontamination meets anticipated removal targets for $\mathrm{AW}-101$; the $\mathrm{AN}-107$ results are less conclusive, although they show that electrochemical processing was able to remove $99 \mathrm{Tc}$. Simulant testing was shown to provide a basis for procedure development; but waste nonhomogeneity and differences in the ${ }^{99} \mathrm{Tc}$ species present in the tank waste show the need for actual waste validation testing.

\section{References}

Blanchard DL Jr, GN Brown, SD Conradson, SK Fadeff, GR Golcar, NJ Hess, GS Klinger, and DE Kurath. 1997. Technetium in Alkaline, High-Salt, Radioactive Tank Waste Supernate:

Preliminary Characterization and Removal. PNNL-11386, Pacific Northwest National Laboratory, Richland, Washington.

Orme RM, AF Mauel, LW Shelton, and EJ Slaathaug. 1996. Tank Waste Remediation System Privatization Process Technical Baseline. WHC-SD-WM-TI-774, Westinghouse Hanford Company, Richland, Washington. 


\section{Contents}

Summary $\ldots \ldots \ldots \ldots \ldots \ldots \ldots \ldots \ldots \ldots \ldots \ldots \ldots \ldots \ldots \ldots \ldots \ldots \ldots$

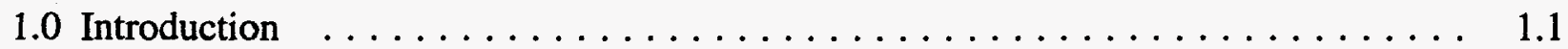

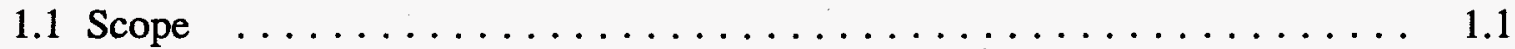

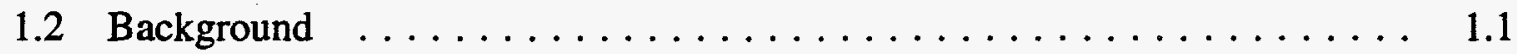

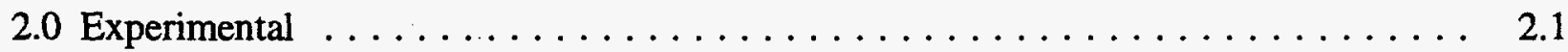

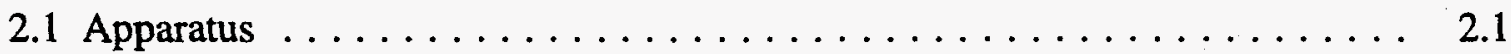

2.1.1 Electro-Oxidation Cell Configuration $\ldots \ldots \ldots \ldots \ldots \ldots \ldots$

2.1.2 Electroreduction Cell Configuration . . . . . . . . . . . 2.3

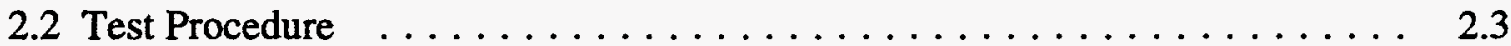

2.2.1 AW-101 Testing Procedure $\ldots \ldots \ldots \ldots \ldots \ldots \ldots \ldots \ldots \ldots \ldots$

2.2.2 AN-107 Testing Procedure $\ldots \ldots \ldots \ldots \ldots \ldots \ldots \ldots \ldots$

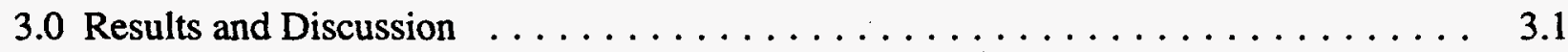

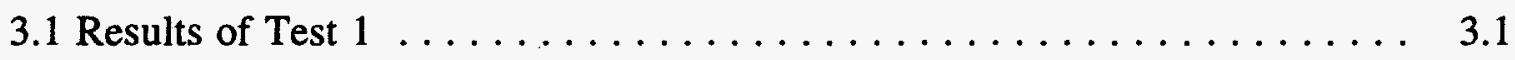

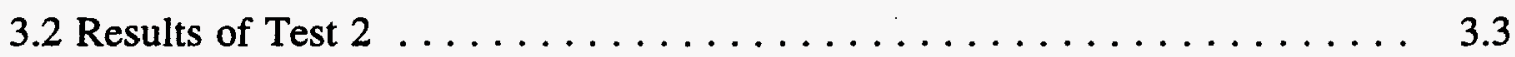

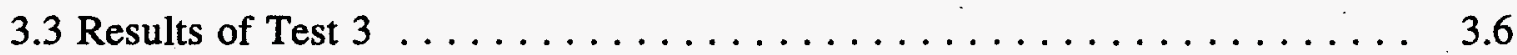

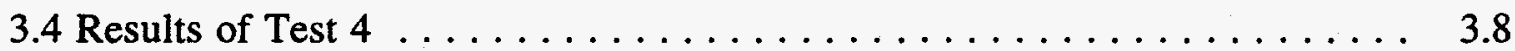

3.5 Results of Test $5 \ldots \ldots \ldots \ldots \ldots \ldots \ldots \ldots \ldots \ldots \ldots \ldots \ldots \ldots$

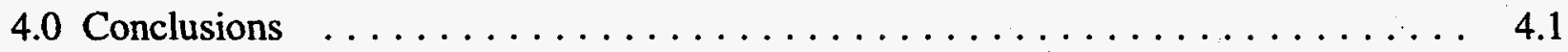

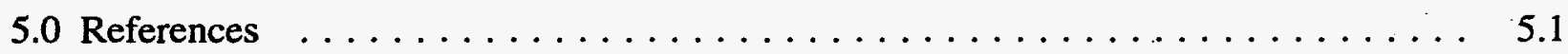




\section{Figures}

2.1 Schematic of Electrochemical Flow Cell Apparatus $\ldots \ldots \ldots \ldots \ldots \ldots \ldots \ldots$

2.2 Photograph of Experimental Flow Cell Apparatus in Fume Hood $\ldots \ldots \ldots \ldots .2 .2$

3.1 ${ }^{99} \mathrm{Tc}$ Concentration Versus Charge Passed During Preoxidation of AW-101 Feed . . . 3.2

3.2 Nonextractable ${ }^{99} \mathrm{Tc}$ Concentration Versus Charge Passed During Preoxidation

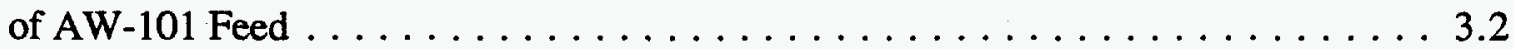

3.3 TOC Versus Charge Passed During Preoxidation of AW-101 Feed . . . . . . . 3.3

3.4 Current Versus Time and Potential Steps During Electroreduction of AW-101 Feed . . 3.4

3.5 Charge Passed Versus Time During Electroreduction of AW-101 Feed . . . . . . . . 3.4

3.6 $99 \mathrm{Tc}$ Concentration Versus Charge Passed During Electroreduction of AW-101 Feed . 3.5

$3.7 \quad{ }^{99} \mathrm{Tc}$ Df Versus Charge Passed During Electroreduction of AW-101 Feed . . . . . . . 3.5

3.8 $\quad{ }^{99} \mathrm{Tc}$ Concentration Versus Charge Passed During Preoxidation of

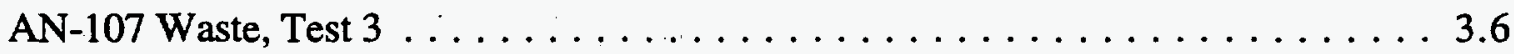

3.9 Nonextractable ${ }^{99} \mathrm{Tc}$ Concentration Versus Charge Passed During Preoxidation

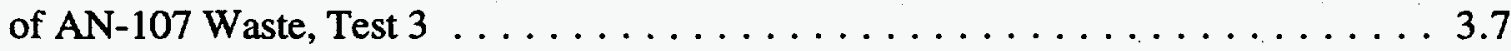

3.10 TOC Versus Charge Passed During Preoxidation of AN-107 Feed, Test $3 \ldots \ldots .8$

$3.11{ }^{99} \mathrm{Tc}$ Concentration Versus Charge Passed During Preoxidation of AN-107 Feed, Test $4 \ldots \ldots \ldots \ldots \ldots \ldots \ldots \ldots \ldots \ldots \ldots . . . \ldots \ldots$

3.12 Nonextractable ${ }^{99} \mathrm{Tc}$ Concentration Versus Charge Passed During Preoxidation

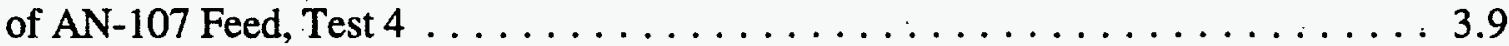

3.13 TOC Versus Charge Passed During Preoxidation of AN-107 Feed, Test $4 \ldots \ldots 3.10$

3.14 Current Versus Time During Electroreduction of AN-107 Waste . . . . . . . . . 3.11

3.15 Current Versus Time and Potential Steps During Electroreduction of AN-107 Feed .. 3.12

3.16 Charge Passed Versus Time During Electroreduction of AN-107 Waste . . . . . . 3.12

3.17 ${ }^{99} \mathrm{Tc}$ Concentration Versus Charge Passed During Electroreduction of AN-107 Feed 3.13

$3.18{ }^{99} \mathrm{Tc}$ Df Versus Charge Passed During Electroreduction of AN-107 Waste . . . . . 3.14 


\section{Tables}

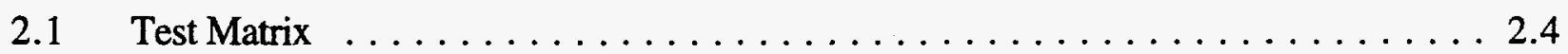

2.2 Composition of AW-101 Supernatant Liquid $\ldots \ldots \ldots \ldots \ldots \ldots \ldots \ldots \ldots \ldots \ldots \ldots \ldots$

2.3 Composition of AN-107 Supernatant Liquid $\ldots \ldots \ldots \ldots \ldots \ldots \ldots \ldots \ldots \ldots \ldots \ldots \ldots \ldots$

3.1 Strontium-90 Concentration Before and After Oxidation $\ldots \ldots \ldots \ldots \ldots \ldots \ldots .7$

3.2 Comparison of Simulant and Actual Waste Decontamination Factors . . . . . . . 3.14 


\subsection{Introduction}

The U.S. Department of Energy's Hanford Site in Richland, Washington, has 177 underground storage tanks that contain approximately 61 million gallons of radioactive waste. A potential cleanup strategy is to retrieve the waste and separate components into high-level and lowlevel waste (Orme et al. 1996). However, some of the tanks contain technetium-99 (99Tc) at concentrations deemed to be unacceptable for ultimate processing and disposal. Conventional extraction processes have been shown to be inefficient at removal of $99 \mathrm{Tc}$ due to the presence of nonpertechnetate species (Blanchard et al. 1997). Electrochemical processing offers the ability to oxidize the nonextractable species through the application of an oxidation potential and subsequently separate the ${ }^{99} \mathrm{Tc}$ by electrodeposition. The purpose of this study is to demonstrate electrochemical processing for the removal of ${ }^{99} \mathrm{Tc}$ from Hanford tank waste supernatant liquids.

\subsection{Scope}

The primary objective of this work is to demonstrate the removal of $99 \mathrm{Tc}$ from Hanford tank waste supernatant liquids. This work will serve to validate simulant testing conducted by AEA Technology (AEAT) and provide the information necessary for a comparison of electrochemical and ion exchange (IX) processing. Simulant testing by AEAT indicated that direct electrochemical reduction of feeds containing organic complexants required a preoxidation of the feed prior to electroreduction separation of ${ }^{99} \mathrm{Tc}$. AEAT developed a procedure based on their simulant testing activities. The simulant solutions were spiked with $99 \mathrm{Tc}$ to simulate waste feeds from Hanford Tanks 241-AW-101 (AW-101) and 241-AN-107 (AN-107). The AEAT process consists of an electrochemical oxidation followed by an electrochemical reduction. This procedure was adopted at PNNL for actual waste testing. The two tank wastes tested are representative of the bounds of nonpertechnetate to pertechnetate ratios expected in the Hanford tank wastes. The first waste feed is from $\mathrm{AW}-101$, a low organic-containing waste feed $(3 \mathrm{~g}$ total organic carbon $/ \mathrm{L}$ in tank) with a low to moderate nonpertechnetate content $(\approx 20 \%$ in tank). The second waste feed is from $\mathrm{AN}-107$, a high organic-containing waste ( $39 \mathrm{~g}$ total organic carbon $\mathrm{L}$, in tank) with a nonpertechnetate content ( $\approx 60 \%$ in tank). Electrochemical processing of the two waste types was conducted, and the ${ }^{99} \mathrm{Tc}$ removal was measured.

\subsection{Background}

Electrodeposition has been extensively used for separation and recovery; for example, the recovery of silver from photographic emulsions, the recovery of metals from plating waste streams, and the refining of metals (Pletcher and Walsh 1993; Walsh 1993). A requirement for removal of the metal is that the reduction of the species occurs in a convenient potential range (i.e., the species be electroactive in the potential range of interest and, in the case of tank waste supernatant liquid, in aqueous solution). Pertechnetate undergoes reduction to the metal or oxide under convenient aqueous reduction potentials. The standard reduction potential for pertechnetate to technetium metal is 0.472 volts $(\mathrm{V})$ and from pertechnetate to $\mathrm{TcO}_{2}$ is $0.738 \mathrm{~V}$. The primary competing reactions during pertechnetate reduction are chromate and nitrate reduction and 
potentially the reduction of water. Hobbs (1992) has shown that pertechnetate will be reduced and deposited in the presence of nitrate for Savannah River type tank wastes. More recent testing conducted by AEAT has shown pertechnetate removal in simulated Hanford tank waste.

The performance of the preoxidation process is quantitatively measured by the extent of nonpertechnetate oxidized and the total organic carbon (TOC) oxidized. Electroreduction performance is measured by monitoring the change in concentration of $99 \mathrm{Tc}$ in the aqueous waste during processing. From the change in ${ }^{99} \mathrm{Tc}$ concentration, the decontamination factor (DF) can be calculated as

$$
\mathrm{DF}=\text { initial technetium concentration/intermediate or final technetium concentration }
$$

The DF removal requirement for ${ }^{99} \mathrm{Tc}$ from Hanford tank waste is undefined but is estimated to be on the order of 5 , which corresponds to obtaining a $80 \%$ removal of the $99 \mathrm{Tc}$ present (Blanchard et al. 1997).

This report describes the electrochemical testing activities completed during FY 1997. The experimental apparatus and approach are described in Section 2. Section 3 contains the results and discussion, and Section 4 contains the conclusions. The references are listed in Section 5. 


\subsection{Experimental}

\subsection{Apparatus}

Figure 2.1 shows the electrochemical flow cell experimental apparatus used for all testing. The apparatus consists of a plate-and-frame flow cell, feed tanks, pumps, and flow meters contained within a radioactive fume hood. Two power supplies were used. A power supply operating under galvanostatic control was used for the feed preoxidation, and a potentiostat was used for electroreduction operation. The power supplies were located outside the hood with the electrical leads passing through penetrations in the hood. A chiller was also used to supply cooling water during the feed preoxidation. Flow cell operation was conducted in the commonly used batch recirculation mode, where the solution from the feed tank was pumped through the flow cell and recirculated back to the feed tank.

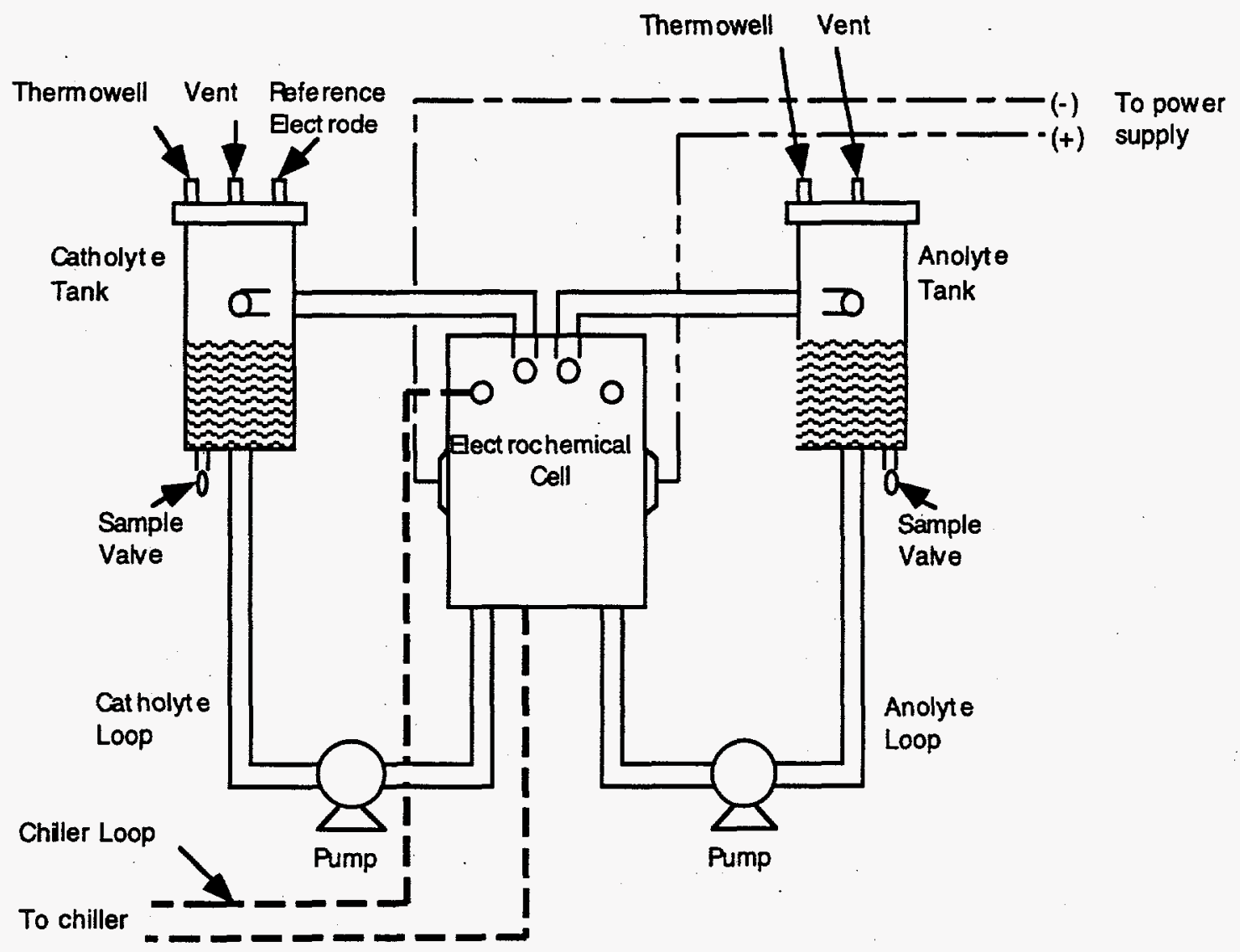

Figure 2.1. Schematic of Electrochemical Flow Cell Apparatus 
The flow cell was the engineering-scale multipurpose (MP) cell commercially available from ElectroCell $\mathrm{AB}$ (Sweden). The MP cell has a base electrode area of $100 \mathrm{~cm}^{2}$, stainless steel base plates, polyvinyliden fluoride (PVDF) turbulence promoting mesh spacers with flow distributors, and Viton ${ }^{\circledR}$ gasketing. Figure 2.2 is a photograph of the assembled flow cell and ancillary equipment contained in the radioactive fume hood.

The anolyte and catholyte tanks were 1-L thick-walled high-density polyethelene (HDPE) bottles. All tubing and fittings were perfluoroalkoxy (PFA) or Teflon ${ }^{\circledR}$. Two centrifugal pumps (March, MTX-MD-3) were used to recirculate the anolyte and catholyte streams. The solution flow rate was controlled by valves at the pump outlets. The flow rate was measured using flow meters (Gilmont) mounted in line with the recirculation loop. Temperature was measured with Type-K thermocouples placed in ceramic thermowells within the anolyte and catholyte reservoirs. The electrochemical cell configurations for the oxidation and reduction testing are described in greater detail below.

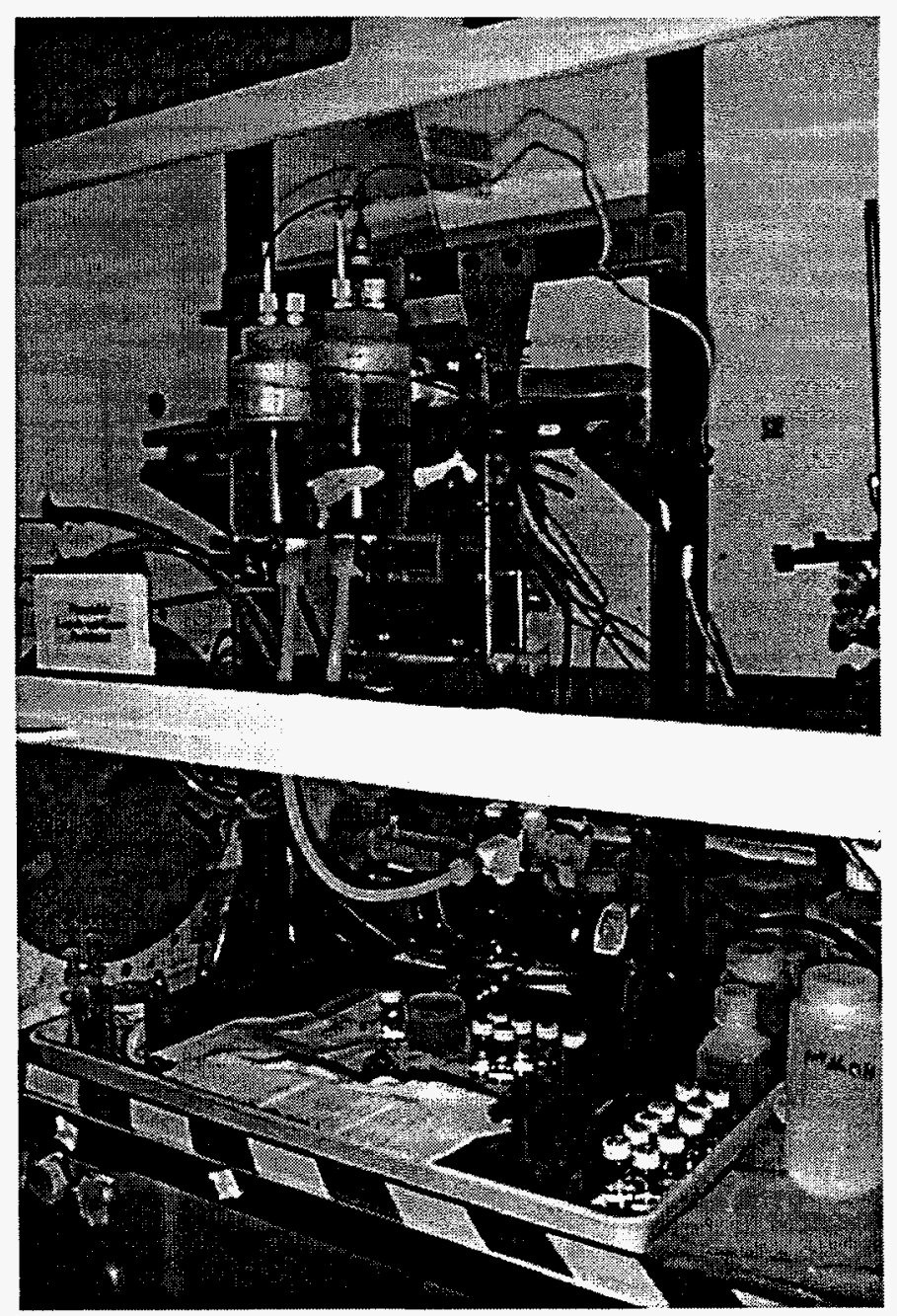

Figure 2.2. Photograph of Experimental Flow Cell Apparatus in Fume Hood 


\subsubsection{Electro-Oxidation Cell Configuration}

The flow cell was configured with three compartments for the preoxidation testing: the anolyte, catholyte, and cooling water compartments. The anolyte and catholyte were separated by an anion exchange membrane (Tokuyama Soda Co. Ltd., Neosepta AMH), and the cooling water was separated from the catholyte and anolyte by the electrodes. The electrodes were standard offthe-shelf MP cell platinized titanium electrodes from ElectroCell AB.

The Model 730 "Boss" Electrochemical Process Control Unit (Electrosynthesis Co. Inc.) was used for the preoxidation testing. The Boss control unit is capable of providing an output of $60 \mathrm{~V}$ and a current up to $50 \mathrm{amps}$ (A). The electrical leads and sense leads for the power supply were passed through penetrations in the fume hood and connected to tabs on the electrodes.

\subsubsection{Electroreduction Cell Configuration}

Prior to the electroreduction testing, the cell was reconfigured with four compartments representing a doubling of the planar electrode area from 100 to $200 \mathrm{~cm}^{2}$. The center electrode was ATJ graphite acting as a current carrier for the lead wool cathode packed onto both surfaces. A total of 5.12 grams of lead wool was packed into the cell spacer adjacent to the graphite electrode surface. The catholyte loop containing the lead wool was separated from the anolyte compartments with cation exchange membranes (Tokuyama Soda Co. Ltd., Neosepta CMX). The outer electrodes (anodes) were DSA (dimensionally stable anode) from ElectroCell AB.

An EG\&G PARC Model 362 scanning potentiostat was used for the electroreduction testing; it was interfaced with the Model 365 current booster to provide up to $10 \mathrm{amps}$ at $30 \mathrm{~V}$ compliance. The electrometer cable was passed through penetrations in the fume hood to the cell and controlling reference electrode, which was a Cole Parmer SCE (Model 55500-09) placed in contact with the feed solution in the catholyte reservoir. During the tests, electroreduction data were recorded with a Fluke Hydra data logger interfaced to a Dell 486 laptop computer.

\subsection{Test Procedure}

Five tests were conducted with two Hanford tank waste supernatant liquids representing feeds with both low and high nonpertechnetate and organic concentrations. Supernatant liquids from Tanks AW-101 and AN-107 were used (Hendrickson 1997). The feeds were cesiumdecontaminated and diluted to a nominal $5 \underline{\mathrm{M}}$ sodium ion concentration before testing to reduce dose and contamination issues, to simulate anticipated retrieved waste compositions, and to enable handling within a fume hood. The as-received AW-101 waste feed contained around 3\% nonpertechnetate, and the AN-107 feed contained nearly $50 \%$ nonpertechnetate. The nonpertechnetate fraction of $99 \mathrm{Tc}$ is measured by passing the tank feeds through an $\mathrm{XX}$ column containing Reillex HPQ resin. The Reillex HPQ will remove the pertechnetate and the fraction of ${ }^{99} \mathrm{Tc}$ remaining is termed nonpertechnetate or nonextractable. The five tests consisted of three preoxidations and two electroreductions, as shown in Table 2.1. Tests 1 and 2 involve the preoxidation and reduction of the AW-101 feed, respectively. In Test 3, a preoxidation of AN-107 waste was conducted to prepare feed for ion exchange column testing to be carried out at a later date. In Test 4 the AN-107 feed was oxidized for subsequent electroreduction testing conducted in Test 5. 
Table 2.1. Test Matrix

\begin{tabular}{|c|c|l||}
\hline Test Number & Hanford Tank Waste & \multicolumn{1}{|c|}{ Test Performed } \\
\hline 1 & AW-101 & Preoxidation \\
\hline 2 & AW-101 & Electroreduction \\
\hline 3 & AN-107 & Preoxidation \\
\hline 4 & AN-107 & Preoxidation \\
\hline 5 & AN-107 & Electroreduction \\
\hline
\end{tabular}

The nominal compositions for AW-101 and AN-107 supernatant liquids before cesium decontamination and before dilution are listed in Tables 2.2 and 2.3 (Blanchard et al. 1997; Van Vleet 1993).

\subsubsection{AW-101 Testing Procedure}

The preoxidation and electroreduction procedures for the Tank AW-101 waste are described in this section. For the preoxidation, $800 \mathrm{~mL}$ of the as-received AW-101 waste sample was placed in the anolyte reservoir. In the catholyte, $1 \mathrm{~L}$ of $1 \mathrm{M} \mathrm{NaOH}$ was used to provide electrical conductivity. The anolyte and catholyte solutions were pumped at a batch recirculation flow rate of $1 \mathrm{~L} / \mathrm{min}$. Power was applied to the electrochemical cell to provide a current density of $400 \mathrm{~mA} / \mathrm{cm}^{2}$ over the six-hour preoxidation duration. A chiller recirculator was used during the preoxidation to maintain the solution temperature below $60^{\circ} \mathrm{C}$ to minimize deterioration of the anion exchange membrane. The anions and water were transported from the cathode compartment across the anion exchange membrane into the anode compartment, resulting in a volume increase in the anolyte. Sample aliquots were taken before applying the power, during the preoxidation testing, and at the conclusion of testing. Both the initial and final aliquots were $10 \mathrm{~mL}$, and the two intermediate samples were $8 \mathrm{~mL}$. Portions of the aliquots were passed through a syringe column containing Reillex HPQ ion exchanger to extract the pertechnetate. The nonextractable $99 \mathrm{Tc}$ passing through the column served as a measure of the extent of nonpertechnetate oxidation. The columns were packed with $3 \mathrm{~mL}$ of the Reillex HPQ and conditioned with $6 \mathrm{M}$ sodium nitrate and $2 \underline{\mathrm{M}}$ sodium hydroxide prior to ion exchanging. Both the aliquots and the ion exchanged samples were collected and submitted for ${ }^{99} \mathrm{Tc}$ determination by inductively coupled plasma/mass spectroscopy (ICP/MS). Portions of the aliquots were also submitted for TOC and ${ }^{90} \mathrm{Sr}$ determination. The time, temperature, overall cell potential, and changes in the anolyte volume were recorded throughout the test. Visual changes in the solution coloring were also noted.

The electroreduction used $1 \mathrm{~L}$ of the preoxidized AW-101 sample placed in the catholyte reservoir of the reconfigured electrochemical cell. The anolyte was $1 \mathrm{~L}$ of $1 \underline{\mathrm{M} \mathrm{NaOH}}$. The electroreduction operation was carried out under potential control. A saturated calomel electrode (SCE) was placed in contact with AW-101 solution through an opening in the catholyte reservoir lid. The potential step operation developed by AEAT was used. The potential was stepped from the open circuit potential $(\approx-0.8 \mathrm{~V}$ versus SCE) in $-0.05 \mathrm{~V}$ increments at one-hour intervals until $1.0 \mathrm{~V}$ versus SCE was reached. The electroreduction was carried out for six hours. Solution flow rates were maintained at $1.2 \mathrm{~L} / \mathrm{min}$ during operation. Aliquots were taken before, during, and 
Table 2.2. AW-101 Supernatant Liquid Composition

\begin{tabular}{|c|c|c|c|}
\hline Radionuclides & $\begin{array}{c}\begin{array}{c}\text { Estimated Concentration } \\
(\mu \mathrm{Ci} / \mathrm{mL})\end{array} \\
.\end{array}$ & & \\
\hline $89190 \mathrm{Sr}$ & $2.7 E+03$ & & \\
\hline $99 \mathrm{Tc}$ & $1.2 \mathrm{E}+02$ & & \\
\hline $137 \mathrm{Cs}$ & $5.4 \mathrm{E}+04$ & & \\
\hline $239 / 240 \mathrm{Pu}$ & $1.8 \mathrm{E}+02$ & & \\
\hline Component & $\begin{array}{c}\text { Estimated Concentration } \\
(\mathrm{g} / \mathrm{L})\end{array}$ & Component & $\begin{array}{c}\text { Estimated Concentration } \\
(\mathrm{g} / \mathrm{L})\end{array}$ \\
\hline$\overline{\mathrm{Ag}}$ & $<3.3 \mathrm{E}-02$ & Mo & $5.8 \mathrm{E}-02$ \\
\hline Al & $2.8 \mathrm{E}+01$ & $\mathrm{NH}_{3}$ & $2.5 \mathrm{E}-01$ \\
\hline $\mathrm{Ba}$ & $<9.3$ E-03 & $\mathrm{NO}_{2}$ & $1.0 \mathrm{E}+02$ \\
\hline$\overline{B i}$ & $<1.2 \mathrm{E}-01$ & $\mathrm{NO}_{3}$ & $2.1 \mathrm{E}+02$ \\
\hline $\mathrm{CN}$ & $2.7 \mathrm{E}-02$ & $\mathrm{Na}$ & $2.3 \mathrm{E}+02$ \\
\hline$\overline{\mathrm{CO}_{3}}$ & $1.2 \mathrm{E}+01$ & $\mathrm{OH}$ & $8.6 \mathrm{E}-01$ \\
\hline $\mathrm{Ca}$ & $3.3 \mathrm{E}-02$ & $\mathrm{PO}_{4}$ & $2.1 \mathrm{E}+00$ \\
\hline $\mathrm{Cd}$ & $<1.2$ E-03 & $\mathrm{Pb}$ & $<3.0 \mathrm{E}-01$ \\
\hline $\mathrm{Cl}$ & $5.2 \mathrm{E}+00$ & $\mathrm{SO}_{4}$ & $1.0 \mathrm{E}+00$ \\
\hline $\mathrm{Cr}$ & $1.6 \mathrm{E}-01$ & $\mathrm{Se}$ & $3.3 \mathrm{E}-05$ \\
\hline $\mathrm{Cu}$ & $<2.4 \mathrm{E}-02$ & $\mathrm{Si}$ & $<1.2 \mathrm{E}-01$ \\
\hline$F$ & $<7.6$ E-02 & TOC & $2.5 \mathrm{E}+00$ \\
\hline $\mathrm{Fe}$ & $<4.4$ E-02 & $\mathrm{Ti}$ & $<4.7 \mathrm{E}-03$ \\
\hline $\mathrm{Hg}$ & $<1.6 \mathrm{E}-04$ & $\mathrm{U}$ & $2.2 \mathrm{E}-01$ \\
\hline $\bar{K}$ & $4.2 \mathrm{E}+01$ & $\mathrm{Zn}$ & $<3.2$ E-01 \\
\hline$\overline{\mathrm{Mg}}$ & $5.2 \mathrm{E}-02$ & $\mathrm{Zr}$ & $<5.0 \mathrm{E}-02$ \\
\hline$\overline{M n}$ & $2.6 \mathrm{E}-02$ & & \\
\hline
\end{tabular}

upon completion of the testing. The aliquots were submitted for $99 \mathrm{Tc}$ determination by ICP/MS. The elapsed time, current, temperature, overall cell potential, and working electrode potential were recorded throughout the test.

\subsubsection{AN-107 Testing Procedure}

The general procedure for the preoxidation and electroreduction of the AN-107 supernatant liquid is similar to that described previously for the AW-101 waste. Differences in feed preparation, solution volume, processing times, and operating conditions are noted below. In order to prepare the required volume of preoxidized $\mathrm{AN}-107$ for both electroreduction testing and ion exchange column testing, two batches of AN-107 waste were preoxidized using the AEAT 
Table 2.3. AN-107 Supernatant Liquid Composition

\begin{tabular}{|c|c|}
\hline Radionuclides & $\begin{array}{l}\text { Estimated Concentration } \\
(\mu \mathrm{Ci} / \mathrm{mL})\end{array}$ \\
\hline${ }^{60} \mathrm{Co}$ & $8.5 \mathrm{E}+02$ \\
\hline${ }^{89 / 90} \mathrm{Sr}$ & $1.5 \mathrm{E}+05$ \\
\hline${ }^{99} \mathrm{Tc}$ & $1.0 \mathrm{E}+02$ \\
\hline${ }^{137} \mathrm{Cs}$ & $4.5 \mathrm{E}+05$ \\
\hline${ }^{154} \mathrm{Eu}$ & $2.7 \mathrm{E}+03$ \\
\hline U-Nat & $7.5 \mathrm{E}-02$ \\
\hline $239 / 240 \mathrm{Pu}$ & $8.9 \mathrm{E}+01$ \\
\hline${ }^{241} \mathrm{Pu}$ & $7.4 \mathrm{E}+02$ \\
\hline${ }^{241} \mathrm{Am}$ & $1.3 \mathrm{E}+02$ \\
\hline Primary Components & $\begin{array}{l}\text { Estimated Concentration } \\
\qquad(\mathrm{g} / \mathrm{L})\end{array}$ \\
\hline $\mathrm{Al}$ & $3.8 \mathrm{E}+00$ \\
\hline $\mathrm{CO}_{3}$ & $6.7 \mathrm{E}+01$ \\
\hline $\mathrm{Fe}$ & $1.8 \mathrm{E}+00$ \\
\hline $\mathrm{NO}_{2}$ & $3.8 \mathrm{E}+01$ \\
\hline $\mathrm{NO}_{3}$ & $1.7 \mathrm{E}+02$ \\
\hline $\mathrm{Na}$ & $2.1 \mathrm{E}+02$ \\
\hline $\mathrm{OH}$ & $8.5 \mathrm{E}-01$ \\
\hline $\mathrm{PO}_{4}$ & $2.8 \mathrm{E}+00$ \\
\hline $\mathrm{SO}_{4}$ & $5.8 \mathrm{E}+00$ \\
\hline TOC & $3.9 \mathrm{E}+01$ \\
\hline
\end{tabular}

procedure for AN-107 supernatant liquid. The procedure called for the addition of sodium hydroxide because of the high organic concentration, which requires a longer preoxidation time than that required for $\mathrm{AW}-101$ and results in the $\mathrm{AN}-107$ feed becoming more diluted. Excessive dilution of the alkaline tank waste results in the precipitation of aluminates, which could plug the pumps, tubing, and the cell. Thus, to minimize the risk of the aluminate precipitation, additional sodium hydroxide was added. Two-hundred milliliters of $20 \mathrm{M} \mathrm{NaOH}$ were added to $740 \mathrm{~mL}$ of the as-received AN-107 waste. The solution was vigorously mixed and allowed to sit for 24 hours before preoxidation testing. 
For the first preoxidation test, $490 \mathrm{~mL}$ of the $\mathrm{NaOH}$-diluted $\mathrm{AN}-107$ feed was used, and the remaining $450 \mathrm{~mL}$ was used for the second preoxidation test. Even though the AN-107 sample had undergone cesium decontamination, a large amount of $90 \mathrm{Sr}$ was present in solution, providing a high dose rate from beta radiation. Therefore, working with the AN-107 supernatant liquid required portable shielding, and no contact handling of vials or bottles was allowed. The process was conducted at a current density of $400 \mathrm{~mA} / \mathrm{cm}^{2}$ over the 16 -hour preoxidation period. The preoxidation was carried out over two consecutive days. The sampling and analytical procedures were the same as those described previously for the AW-101 preoxidation.

The first batch of preoxidized AN-107 waste sample was archived for ion exchange column flow testing. The second batch of preoxidized AN-107 was used for the electroreduction. The electrochemical cell was reconfigured with new lead wool cathodes for the electroreduction test. Approximately $890 \mathrm{~mL}$ of the preoxidized $\mathrm{AN}-107$ feed was used for the electroreduction. The procedure is the same as that described for the AW-101 electroreduction except that before the controlled potential step operation, a short period of constant current reduction was conducted. The constant current operation was followed first by the application of no potential bias and then the AEAT potential step operation procedure. The constant current operation totaled approximately 30 minutes over a 200 -minute period, and the potential step operation lasted eight hours. During operation, the solution flow rates were maintained at $1.0 \mathrm{~L} / \mathrm{min}$. Aliquots were taken before, during, and upon completion of the testing. The aliquots were submitted for ${ }^{99} \mathrm{Tc}$ analysis by ICP/MS. The elapsed time, current, temperature, overall cell potential, and working electrode potential were recorded throughout the test period. 


\subsection{Results and Discussion}

The information obtained during the removal of $99 \mathrm{Tc}$ from Hanford tank supernatant liquids by electrochemical processing was used to validate simulant test studies and support a comparison between electrochemical and ion-exchange ${ }^{99} \mathrm{Tc}$ removal. The test results are described in the following sections.

\subsection{Results of Test 1}

In the first test, Test 1 , the Tank AW-101 supernatant liquid was preoxidized. The primary objective of the electro-oxidation was to oxidize nonpertechnetate (nonextractable) species to pertechnetate (extractable). Figure 3.1 shows the $99 \mathrm{Tc}$ concentration over the course of the sixhour process. The average overall cell potential was $8 \mathrm{~V}$ at a steady state operating temperature of $59^{\circ} \mathrm{C}$. During the test the anolyte volume increased from 800 to $1185 \mathrm{~mL}$, an increase of $385 \mathrm{~mL}$. This change in volume during the course of the test was accounted for because all concentrations are reported with respect to the initial feed volume. In Figure 3.1, the ${ }^{99} \mathrm{Tc}$ concentration is plotted against the charge passed, which for constant current operation is directly proportional to the time. The ${ }^{99} \mathrm{Tc}$ concentration data are shown with the estimated analytical error at $\pm 10 \%$ of the reported data value. The overall $99 \mathrm{Tc}$ concentration does not change over the duration of the test, demonstrating that ${ }^{99} \mathrm{Tc}$ is not lost by transport across the membrane or lost within the system.

In Figure 3.2, the $99 \mathrm{Tc}$ concentration is again plotted against the charge passed, but the difference is that the ${ }^{99} \mathrm{Tc}$ concentration represents the amount of nonextractable ${ }^{99} \mathrm{Tc}$ present. The nonextractable ${ }^{99} \mathrm{Tc}$ is believed to be in the $(+4)$ oxidation state and complexed and therefore is not readily removed by IX. After oxidation, the ${ }^{99} \mathrm{Tc}$ is believed to be present in the $(+7)$ oxidation state as pertechnetate which is readily removed by existing IX materials. In Figure 3.2, the electrochemical oxidation results in a decrease of the nonextractable ${ }^{99} \mathrm{Tc}$ concentration from 0.08 to $0.04 \mu \mathrm{g} / \mathrm{mL}$. Approximately $50 \%$ of the nonpertechnetate present is oxidized, with the majority of the oxidation occurring within the passage of $2 \times 105$ Coulombs (C) or after only $20 \%$ of the experimental time period. It is not known if the remaining nonextractable $99 \mathrm{Tc}$ is recalcitrant or if the reduction in concentration reduces the oxidation efficiency.

The electrochemical oxidation also results in destruction of organic compounds. The extent of TOC destruction was measured over the course of the oxidation, as shown in Figure 3.3. The TOC concentration, plotted against the charge passed, decreases from 1500 to less than $30 \mu \mathrm{g} / \mathrm{mL}$, a destruction extent of $>98 \%$. The rate of TOC destruction is observed to decrease over time due to the corresponding decrease in TOC concentration resulting in a reduction of the oxidation efficiency. Simulant testing by AEAT has indicated that the destruction of organics is important for obtaining good $99 \mathrm{Tc}$ DFs. AEAT will be providing a report on their simulant testing later this year. 


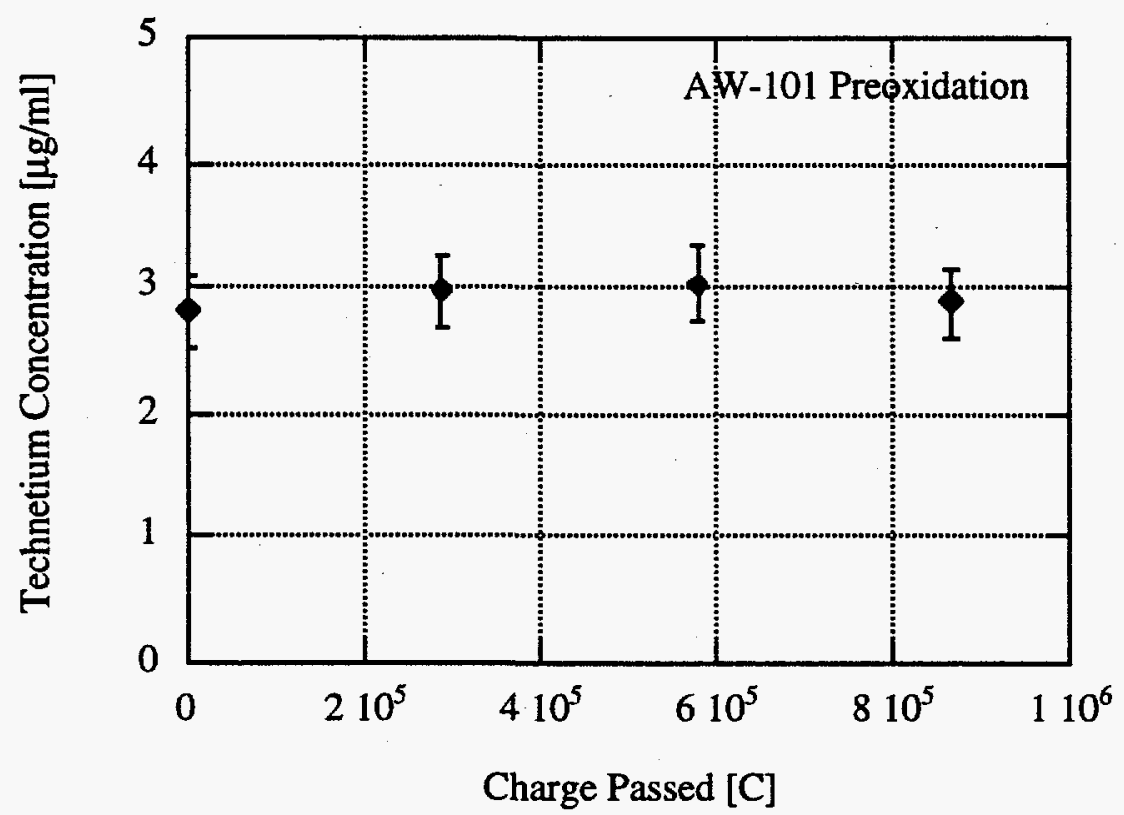

Figure 3.1. ${ }^{99} \mathrm{Tc}$ Concentration Versus Charge Passed During Preoxidation of AW-101 Feed

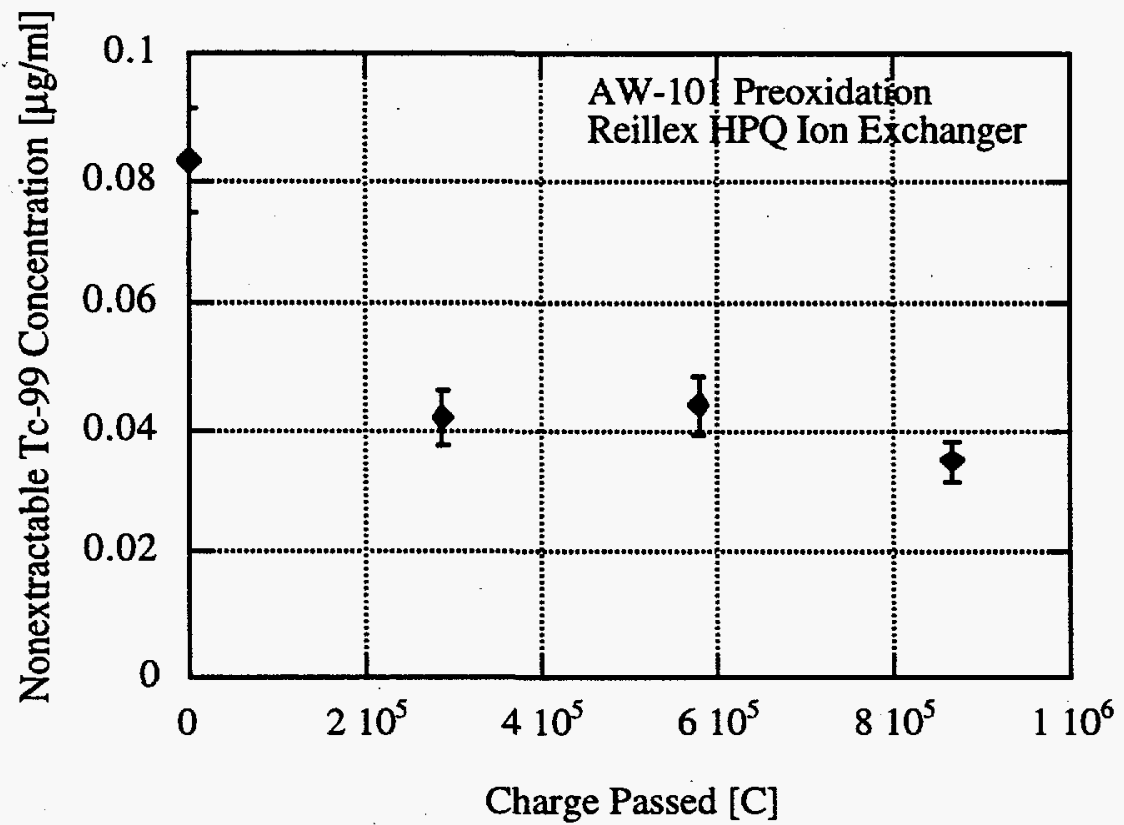

Figure 3.2. Nonextractable $99 \mathrm{Tc}$ Concentration Versus Charge Passed During Preoxidation of AW-101 Feed 


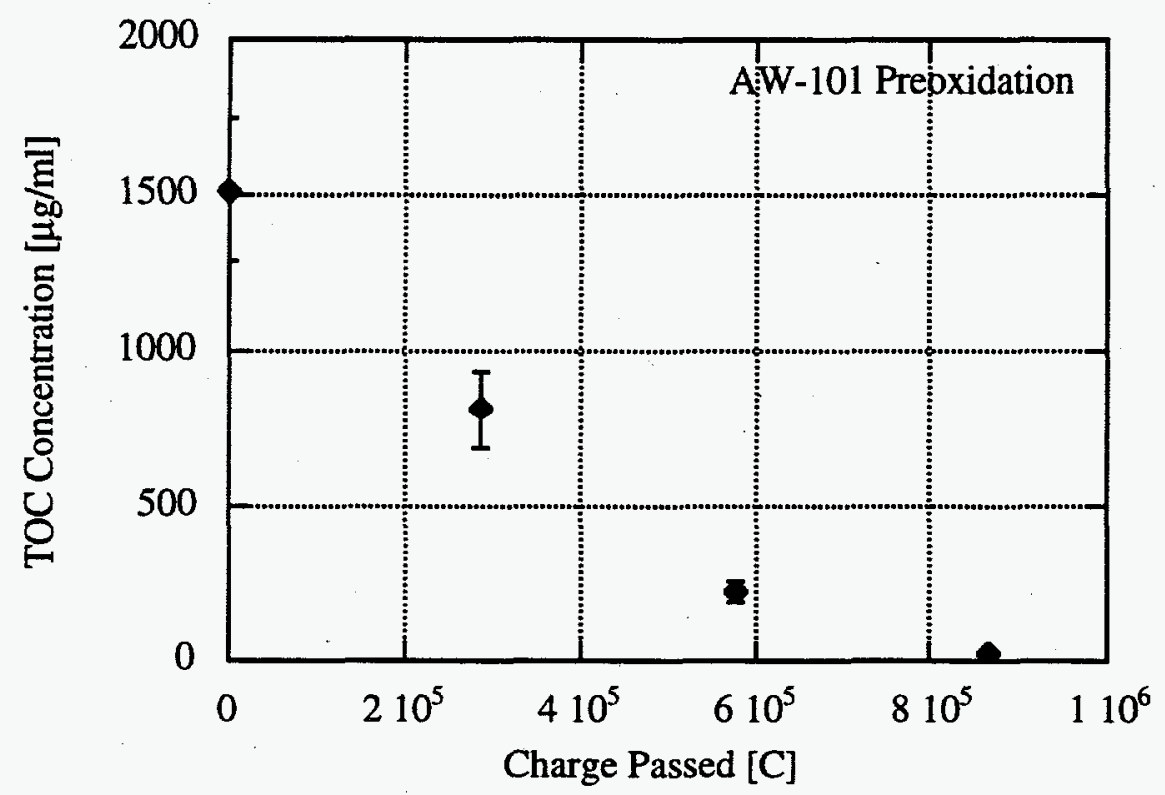

Figure 3.3. TOC Versus Charge Passed During Preoxidation of AW-101 Feed

The destruction of TOC also results in the decomplexation of complexed metals present in the supernatant liquid. One metal of interest is $90 \mathrm{Sr}$ because of difficulties associated with its separation when complexed. The preoxidation process is expected to decomplex the $90 \mathrm{Sr}$, resulting in a decrease of ${ }^{90} \mathrm{Sr}$ in solution. However, in the $\mathrm{AW}-101$ feed the level of $90 \mathrm{Sr}$ was below the detection limits of $3 \times 10^{-4} \mu \mathrm{Ci} / \mathrm{mL}$.

\subsection{Results of Test 2}

Next the preoxidized AW-101 supernatant liquid was used for electroreduction testing. For Test 2, the potential step reduction developed by AEAT was used. Figure 3.4 shows the current over time and the corresponding potential step operation. The current passed represents the deposition of technetium as well as the reduction of other species such as $\mathrm{Cr}(\mathrm{VI})$ and nitrate. During testing, the solution color was observed to change from a deep yellow to green and further to a greenish-gray. This color change is indicative of the reduction of $\mathrm{Cr}(\mathrm{VI})$ to $\mathrm{Cr}(\mathrm{III})$ and serves as a visual indicator of reduction. The area under the current versus time curve was integrated to give the charge passed. Figure 3.5 shows the charge passed versus time during the electroreduction. The curve shows that the majority of charge is passed in the first 180 minutes, which corresponds to the largest change in the ${ }^{99} \mathrm{Tc}$ concentration.

Figure 3.6 shows the decrease in ${ }^{99} \mathrm{Tc}$ concentration from 2.8 to less than $0.15 \mu \mathrm{g} / \mathrm{mL}$ over the course of the six-hour electroreduction test. The amount of $99 \mathrm{Tc}$ removed corresponds to $95 \%$, giving a DF of 19. Figure 3.7 shows the change in DF compared with the charge passed. The 


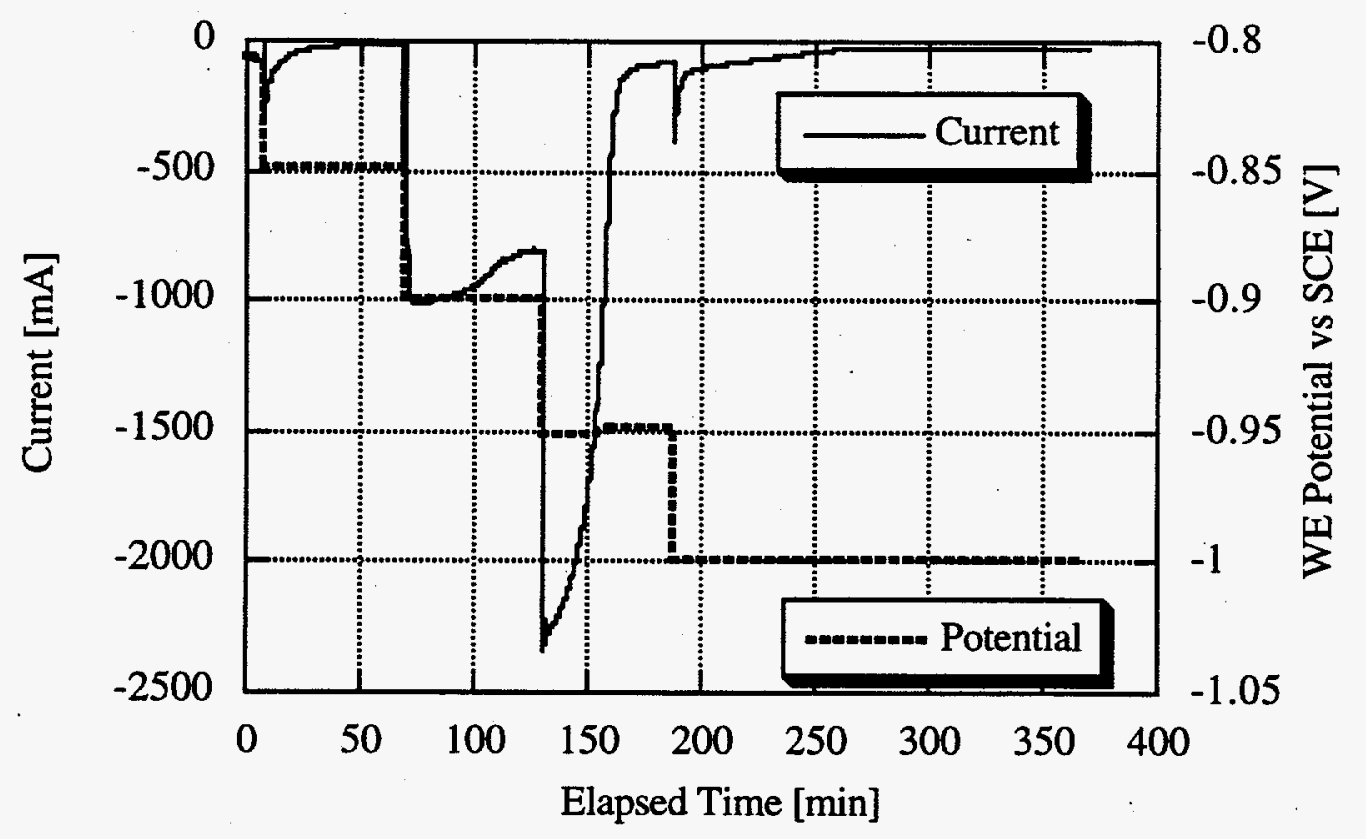

Figure 3.4. TOC Versus Charge Passed During Preoxidation of AW-101 Feed

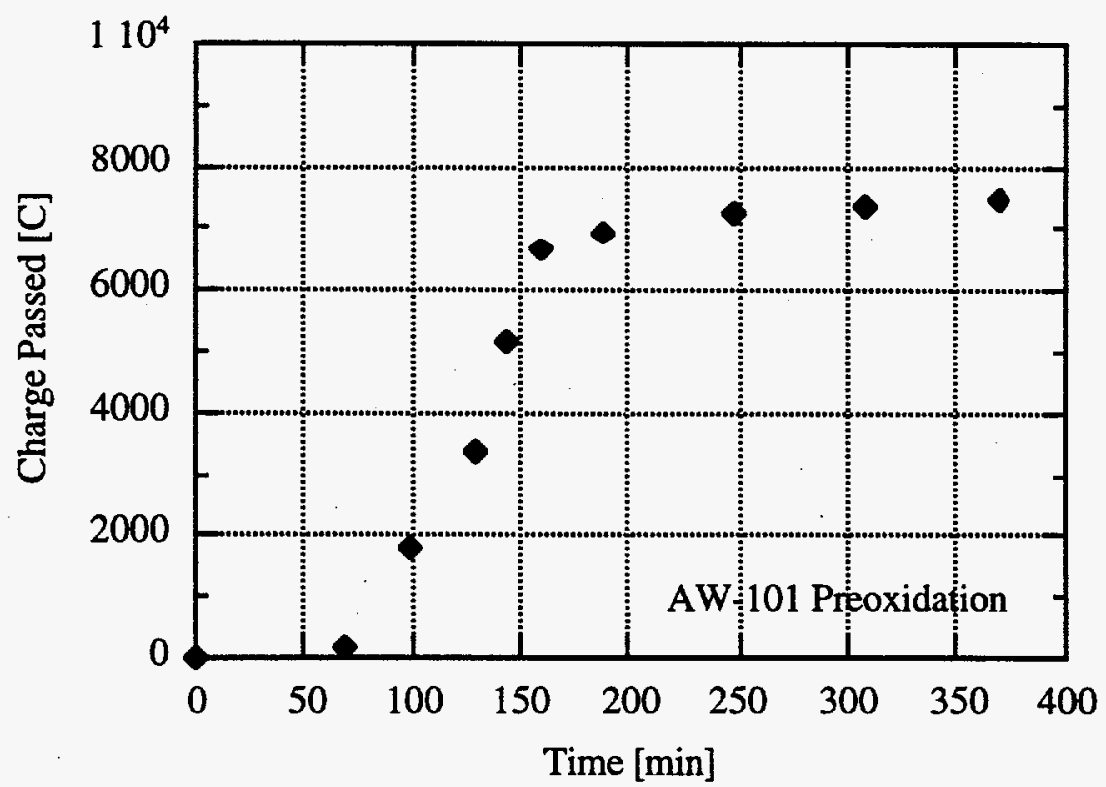

Figure 3.5. Charge Passed Versus Time During Electroreduction of AW-101 Feed 


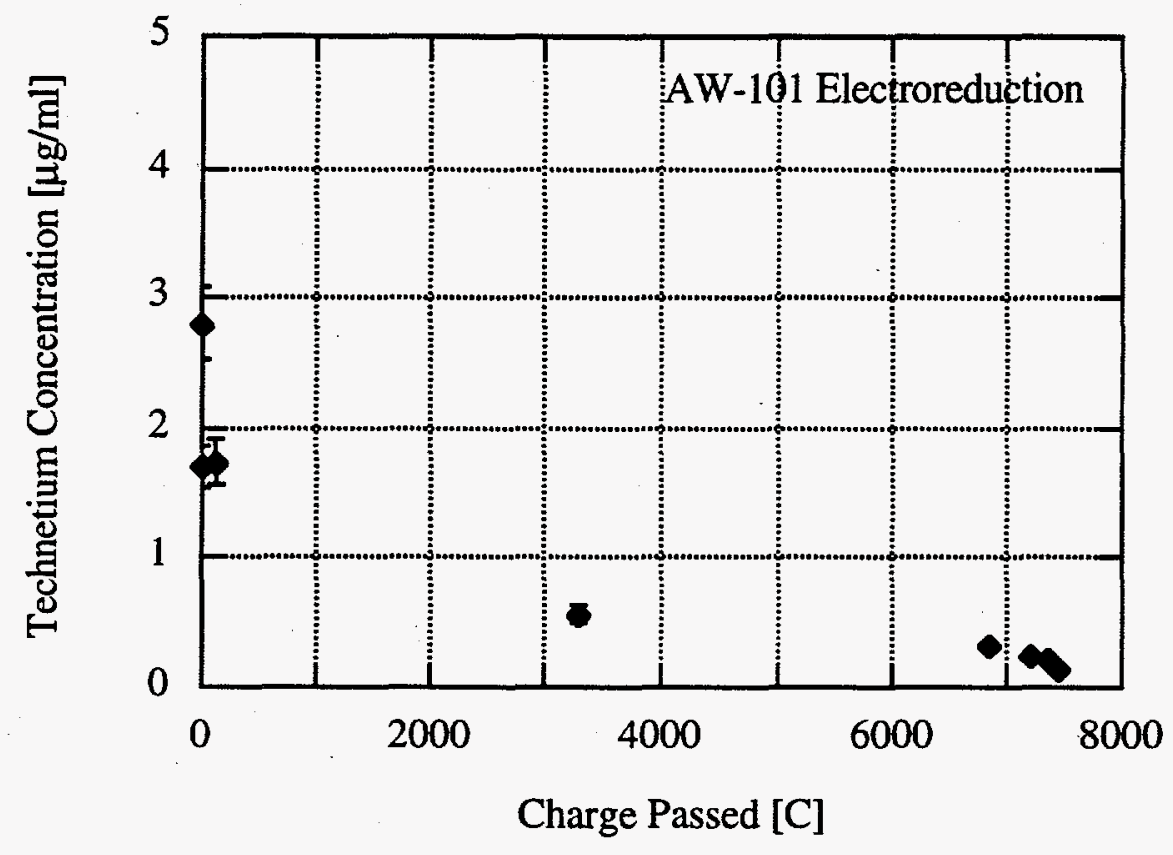

Figure 3.6. ${ }^{99} \mathrm{Tc}$ Concentration Versus Charge Passed During Electroreduction of AW-101 Feed

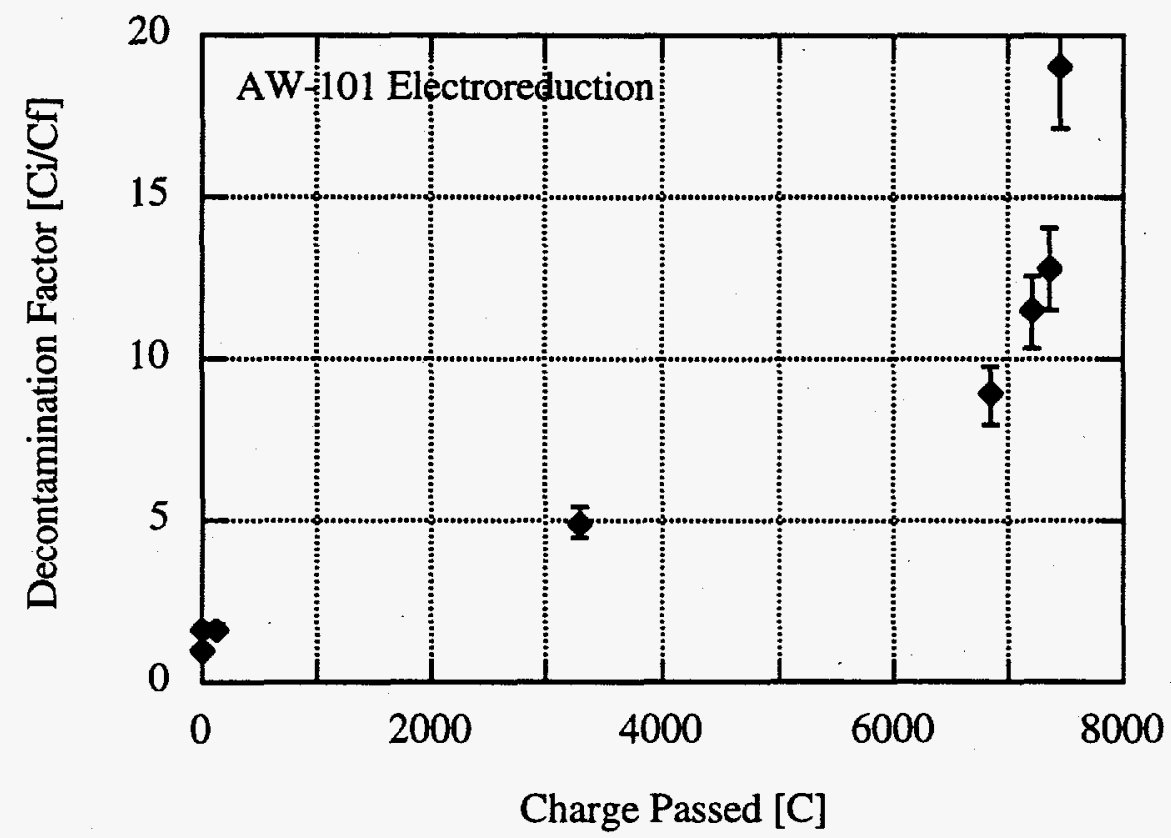

Figure 3.7. ${ }^{99} \mathrm{Tc}$ DF Versus Charge Passed During Electroreduction of AW-101 Feed 
technetium is believed to be reduced from pertechnetate to technetium metal or technetium dioxide and deposited on the cathode. Because the ${ }^{99} \mathrm{Tc}$ is deposited on the cathode, a lower concentration of ${ }^{99} \mathrm{Tc}$ is measured in solution. A DF of approximately 5 is considered sufficient to meet anticipated target removals. At the end of the test, the DF was still increasing, indicating that additional electroreduction could lead to higher DFs.

\subsection{Results of Test 3}

The third test consisted of preparing AN-107 feed for IX column flow testing. Because of the higher organic concentration in the $\mathrm{AN}-107$ waste feed, the preoxidation was carried out for 17 hours over two consecutive days. The overall cell potential averaged $9 \mathrm{~V}$ for the duration of the preoxidation. The steady-state operating temperature was maintained near $50^{\circ} \mathrm{C}$ with the recirculating chiller. Over the course of the preoxidation the anolyte volume increased from $490 \mathrm{~mL}$ to $1835 \mathrm{ml}$, an increase in volume of about 2.7 times. This volume change is accounted for because all concentrations are reported with respect to the initial feed volume.

Figure 3.8 shows the $99 \mathrm{Tc}$ concentration plotted versus the charge passed. Under constant current operation the charge passed is directly proportional to the time. As expected, the overall 99Tc concentration does not significantly change over time during preoxidation. This indicates that ${ }^{99} \mathrm{Tc}$ is not lost by transport across the membrane or lost within the system. Figure 3.9 shows the nonextractable ${ }^{99} \mathrm{Tc}$ concentration plotted against the charge passed. The nonextractable $99 \mathrm{Tc}$ concentration decreases from 1.0 to $0.2 \mu \mathrm{g} / \mathrm{mL}$ over the course of the test. The percentage of

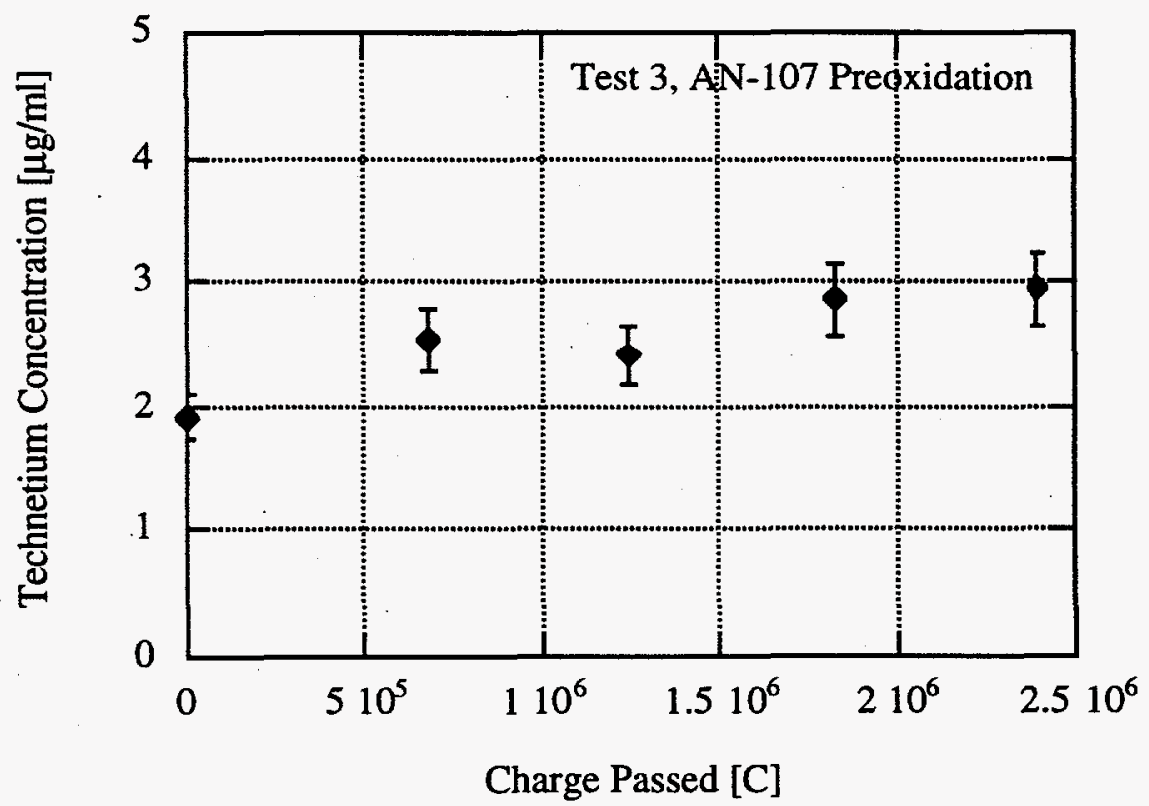

Figure 3.8. ${ }^{99} \mathrm{Tc}$ Concentration Versus Charge Passed During Preoxidation of AN-107 Waste, Test 3 


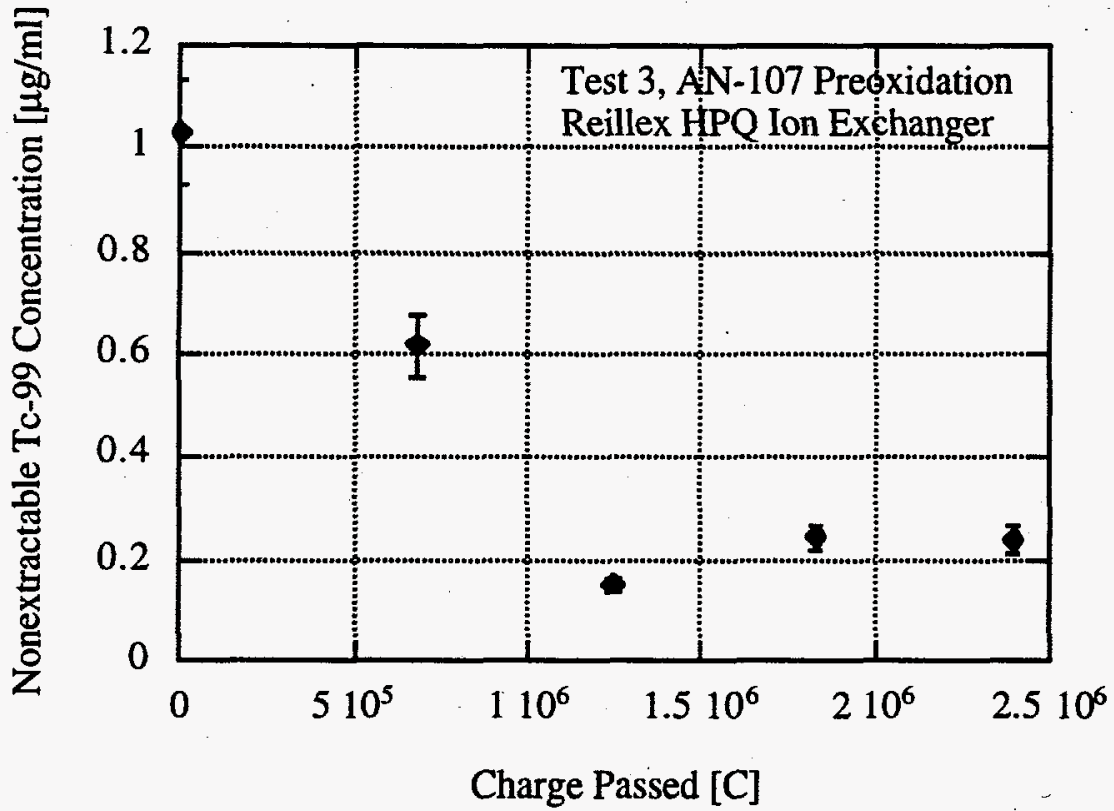

Figure 3.9. Nonextractable ${ }^{99} \mathrm{Tc}$ Concentration Versus Charge Passed During Preoxidation of AN-107 Waste, Test 3

nonpertechnetate decreases from $50 \%$ before the oxidation to less $12 \%$ after the oxidation. The majority of the oxidation of nonpertechnetate occurs within the first third of the experiment. The amount of nonextractable $99 \mathrm{Tc}$ oxidized was $>75 \%$.

Examination of the TOC concentration in Figure 3.10 shows a reduction from approximately $14,000 \mu \mathrm{g} / \mathrm{mL}$ to less than $1000 \mu \mathrm{g} / \mathrm{mL}$, giving a destruction extent of $93 \%$ over the duration of the test. The TOC destruction rate corresponds to $2.6 \times 10^{-6} \mathrm{~g} \mathrm{TOC} / \mathrm{C}$, which is of the same order previously obtained for similar Hanford tank wastes (Elmore and Lawrence 1996). The destruction of TOC results in the decomplexation of metal complexes contained in the supernatant liquid. The change in $90 \mathrm{Sr}$ concentration in the supernatant liquid was measured. Table 3.1 shows the $90 \mathrm{Sr}$ concentration before and after electrochemical oxidation. The $90 \mathrm{Sr}$ in solution decreased by approximately $10 \%$ as a result of the oxidation.

\subsection{Results of Test 4}

The fourth test consisted of preoxidation of AN-107 feed prior to electroreduction testing. The AN-107 preoxidation was carried out for 16 hours. The overall cell potential averaged $6 \mathrm{~V}$ during the preoxidation. The steady-state operating temperature was approximately $40^{\circ} \mathrm{C}$. Over the course of the preoxidation the anolyte volume increased from 450 to $1205 \mathrm{~mL}$, an increase of $755 \mathrm{~mL}$. The volume change for Test 4 was about $60 \%$ of that obtained for the preoxidation in 


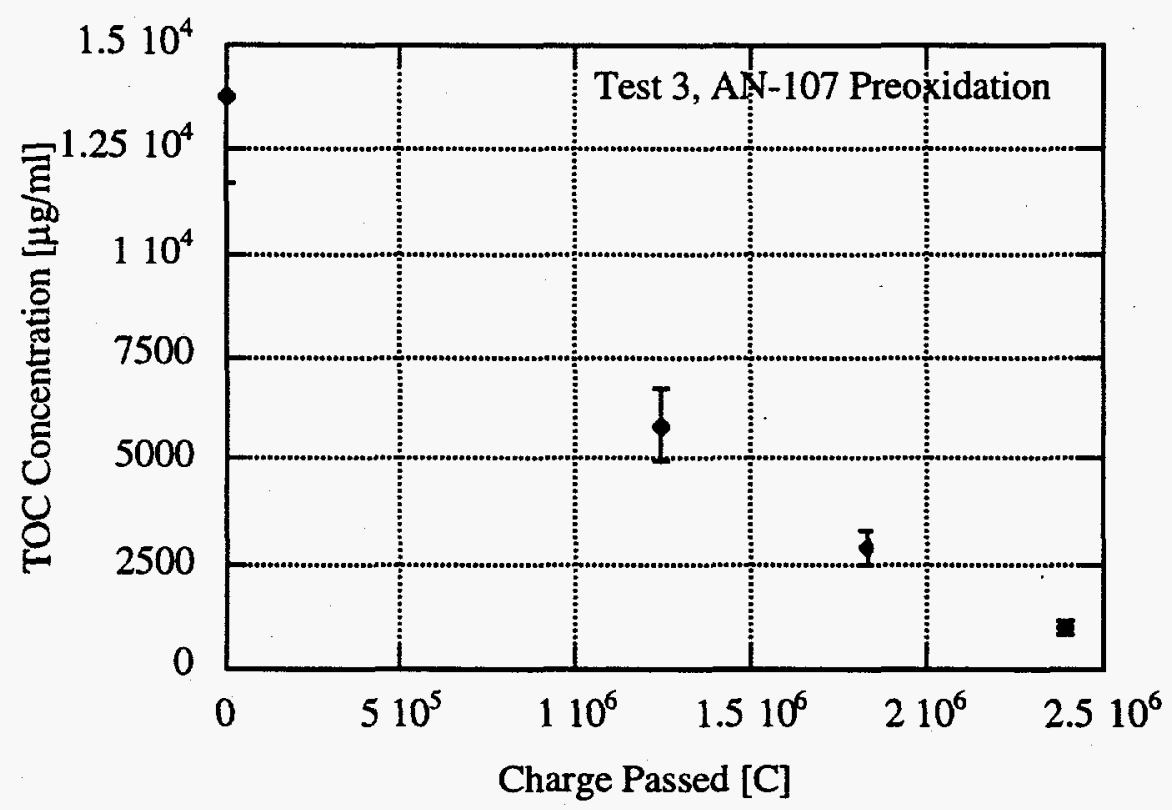

Figure 3.10. TOC Versus Charge Passed During Preoxidation of AN-107 Feed, Test 3

Test 3. This difference in volume change is attributed to the difference in operating potentials, $6 \mathrm{~V}$ versus $9 \mathrm{~V}$, and the operating temperature. It appears that these operating parameters can both directly and indirectly influence the transport of anions and water across the membrane.

The $99 \mathrm{Tc}$ concentration is plotted against the charge passed in Figure 3.11. Under constant current operation the charge passed is directly proportional to the time. As expected, the overall ${ }^{99} \mathrm{Tc}$ concentration does not change during preoxidation. The ${ }^{99} \mathrm{Tc}$ is not lost by transport across the membrane or lost within the system. Figure 3.12 shows the nonextractable ${ }^{99} \mathrm{Tc}$ concentration plotted against the charge passed. The nonextractable $99 \mathrm{Tc}$ concentration decreases from 1.1 to $0.5 \mu \mathrm{g} / \mathrm{mL}$ after 16 hours. The percentage of nonpertechnetate decreases from $50 \%$ before oxidation to less $22 \%$ after oxidation. The amount of nonpertechnetate oxidized in Test 4 was not quite

Table 3.1. Strontium-90 Concentration Before and After Oxidation

\begin{tabular}{|c|c|c|c||}
\hline Test Number & $\begin{array}{c}\text { 90Sr Before Oxidation } \\
(\mu \mathrm{Ci})\end{array}$ & $\begin{array}{c}{ }^{90} \text { Sr After Oxidation } \\
(\mu \mathrm{Ci})\end{array}$ & $\begin{array}{c}\text { Removal } \\
(\%)\end{array}$ \\
\hline 1 & Below detection limit & Below detection limit & N/A \\
\hline 3 & 7546 & 6811 & 9.7 \\
\hline 4 & 8055 & 7470 & 7.3 \\
\hline $\begin{array}{c}4 \text { (sample filtered with } \\
0.45 \mu \text { m pore size filter) }\end{array}$ & 7875 & 6210 & 21 \\
\hline
\end{tabular}




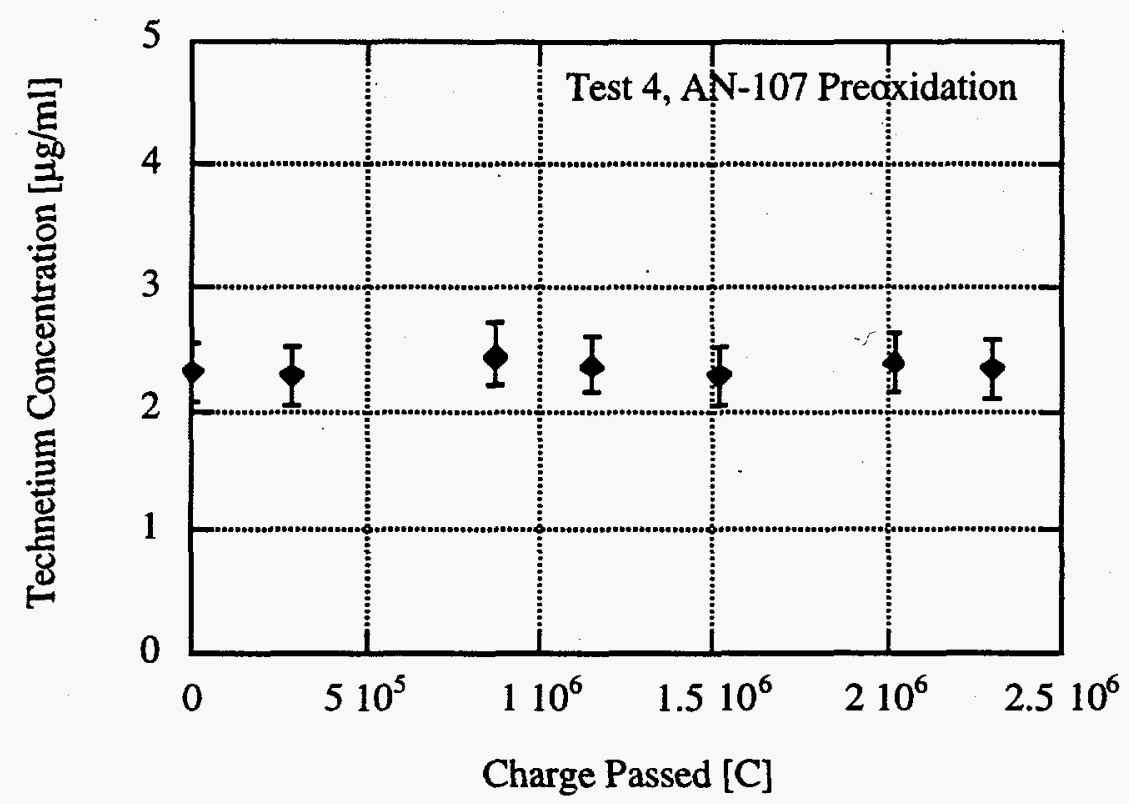

Figure 3.11. ${ }^{99} \mathrm{Tc}$ Concentration Versus Charge Passed During Preoxidation of AN-107 Feed, Test 4

as good as Test 3 for the same charge passed. The difference in oxidation extents and incomplete oxidation of the nonextractable ${ }^{99} \mathrm{Tc}$ cannot be attributed to any single factor, although the poor TOC destruction or recalcitrant species may play a part.

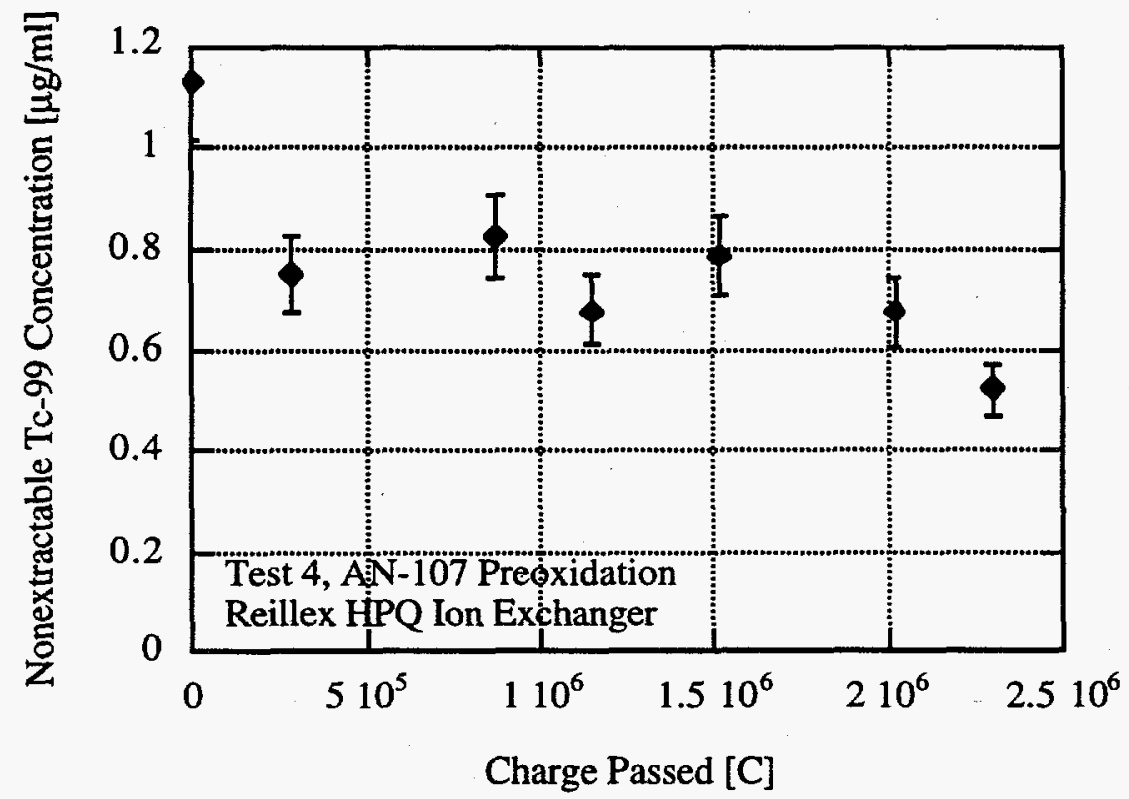

Figure 3.12. Nonextractable ${ }^{99} \mathrm{Tc}$ Concentration Versus Charge Passed During Preoxidation of AN-107 Feed, Test 4 
Figure 3.13 shows the TOC concentration plotted against the charge passed. Examination of the data shows no reduction in TOC. This is unexpected based on the Test 3 oxidation results and because the nonextractable $99 \mathrm{Tc}$ concentration data indicate some oxidation occurred. The reasons for the negligible organic destruction are speculative with the limited test data available. The feed inhomogeneity or operating temperature would seem to be the most likely candidates considering the differences between Test 3 and Test 4 . In Test 3 the feed was retrieved from the top half of the bottle; the bottom half was used for Test 4 . The feeds were mixed thoroughly before transfer to the electrochemical system reservoir, although a denser, darker material began to settle immediately upon stopping agitation. It was noted that the solution in Test 4 appeared to be slightly darker and seemed thicker or more viscous than that used for Test 3 . It may be that the organic components present in the denser Test 4 batch comprise different components, whereby destruction of TOC results in the formation of more refractory organics. In this case one would achieve some decomplexation or destruction of the organics, but the overall TOC may not change. The assumption of waste nonhomogeneity is supported by the visual observations described above and the fact that the initial TOC concentrations of Tests 3 and 4 were different. In Test 4 the initial TOC concentration was about $30 \%$ higher than that reported for Test 3.

The effect of oxidation on the ${ }^{90} \mathrm{Sr}$ concentration in solution is shown in Table 3.1. In Test 3 the decrease in $90 \mathrm{Sr}$ activity was around $10 \%$; it was slightly lower, at 7\%, in Test 4 . Additional samples were taken during Test 4 , and the initial and final aliquots were filtered through $0.45 \mu \mathrm{m}$ filters. The filtrate data with solids greater than $0.45 \mu \mathrm{m}$ removed show a further decrease in $90 \mathrm{Sr}$ activity up to $21 \%$. This indicates that ${ }^{90} \mathrm{Sr}$ is undergoing decomplexation and forming small particulates. The removals obtained seem low considering visual observations and dose rate measurements on the sample containers. A significant amount of precipitate was observed to settle after completion of testing. Dose rate measurements indicated that $90 \%$ of the dose rate was concentrated at the bottom of the container in the location of the precipitate. Filtration in Test 4 resulted

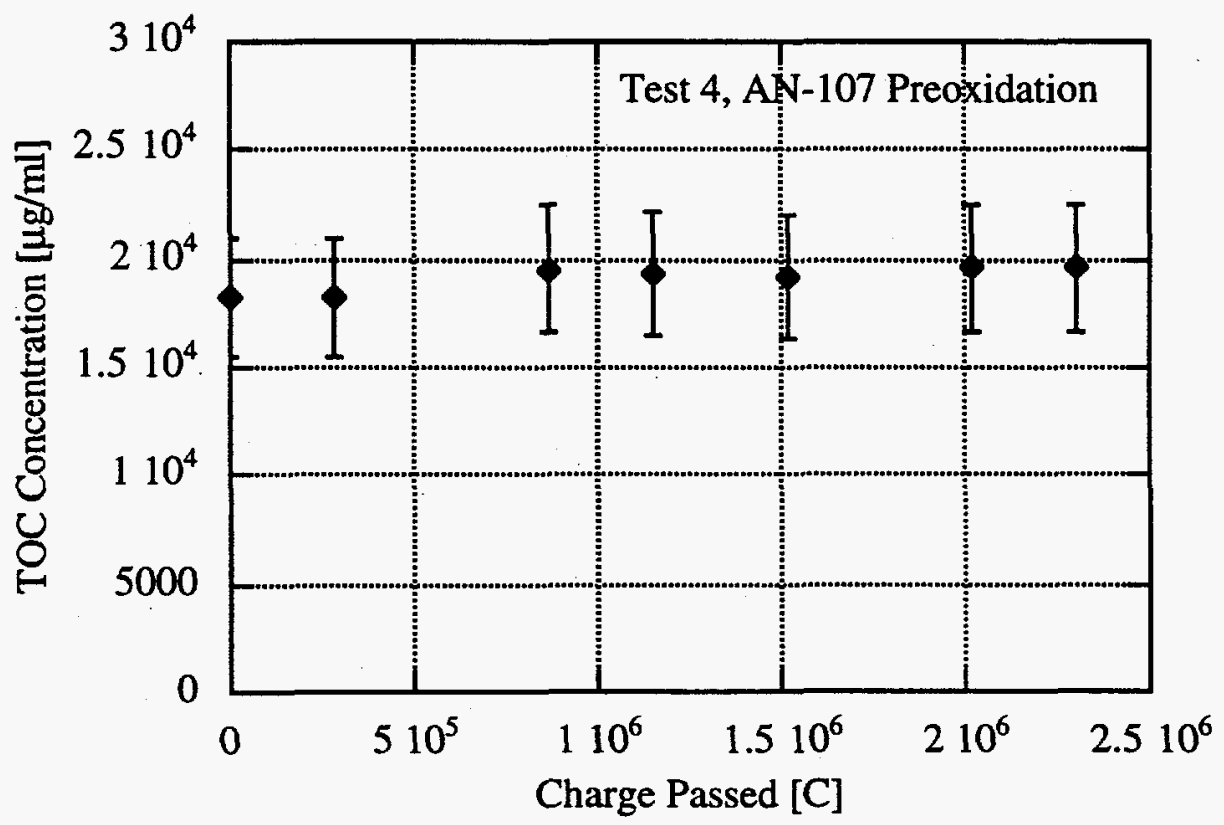

Figure 3.13. TOC Versus Charge Passed During Preoxidation of AN-107 Feed, Test 4 
in a factor of 3 dose increase over the unfiltered sample. Removal might be expected to be even higher for a filtered sample in Test 3 because better TOC destruction was obtained.

\subsection{Results of Test 5}

Finally, in Test 5, the preoxidized AN-107 tank waste supernatant liquid was electroreduced. A potential step reduction was used, similar to Test 2; however, a portion of the test involved constant current operation. Figure 3.14 shows the current over time during the constant current operation. A sample aliquot was taken before the test started, at 125 minutes, and just before potential step operation. A negative current corresponds to a cathodic or reduction current; a positive current is anodic or oxidative. After the constant current operation, the AEAT potential step reduction was used. Figure 3.15 shows the current during the course of the reduction and on the corresponding potential steps. Because of the large amount of brown coloration coming from iron hydroxide, a change in solution color during the test was not observed. The area under the current versus time curve was integrated to give the charge passed and is shown in Figure 3.16 for both constant current and constant potential operation. Approximately $8000 \mathrm{C}$ were passed during the constant current operation and $5000 \mathrm{C}$ during the potential step reduction.

Corresponding to the charge passed in Figure 3.16, Figure 3.17 shows the decrease in ${ }^{99} \mathrm{Tc}$ concentration from 2.1 to less than $0.5 \mu \mathrm{g} / \mathrm{mL}$ over the course of the 12-hour electroreduction test. The largest change in ${ }^{99} \mathrm{Tc}$ concentration occurred during the constant current operation. From 0 to $8000 \mathrm{C}$ the decrease in the ${ }^{99} \mathrm{Tc}$ concentration is due to the constant current reduction.

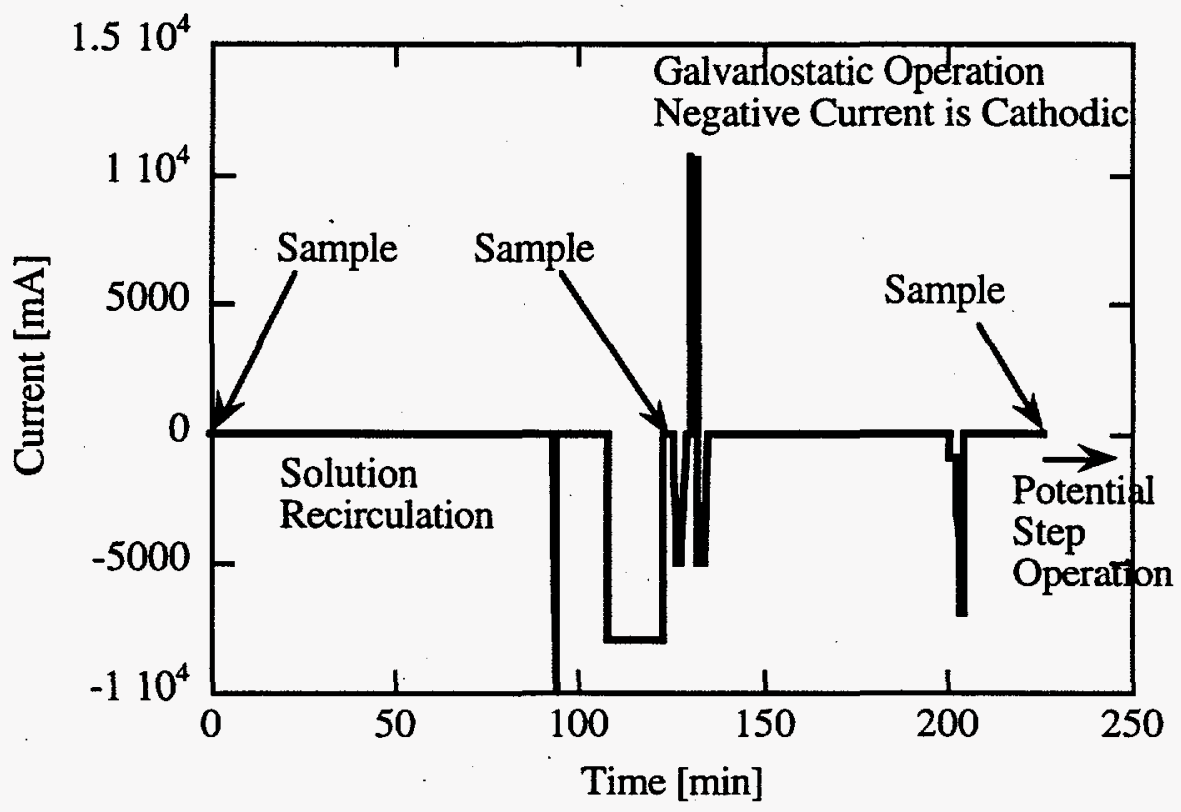

Figure 3.14. Current Versus Time During Electroreduction of AN-107 Waste 


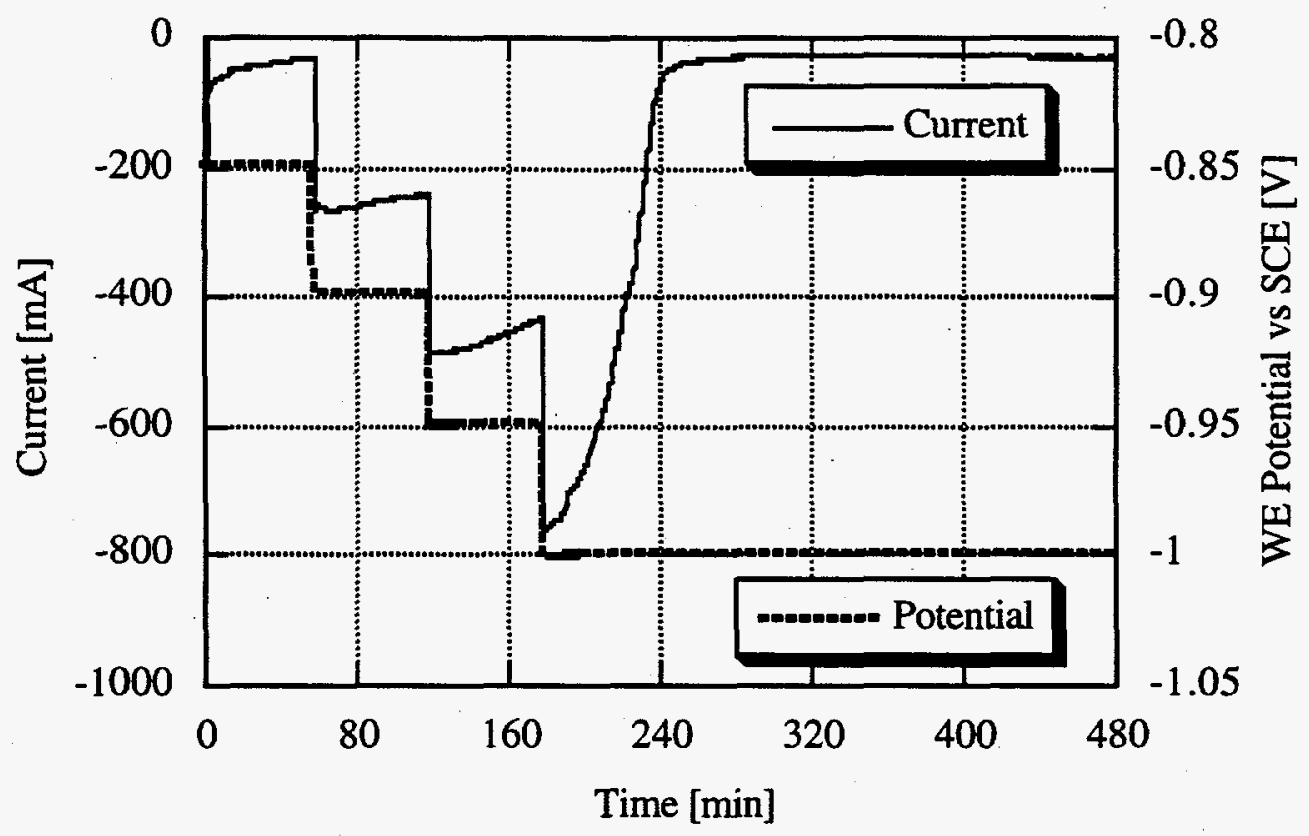

Figure 3.15. Current Versus Time and Potential Steps During Electroreduction of AN-107 Feed

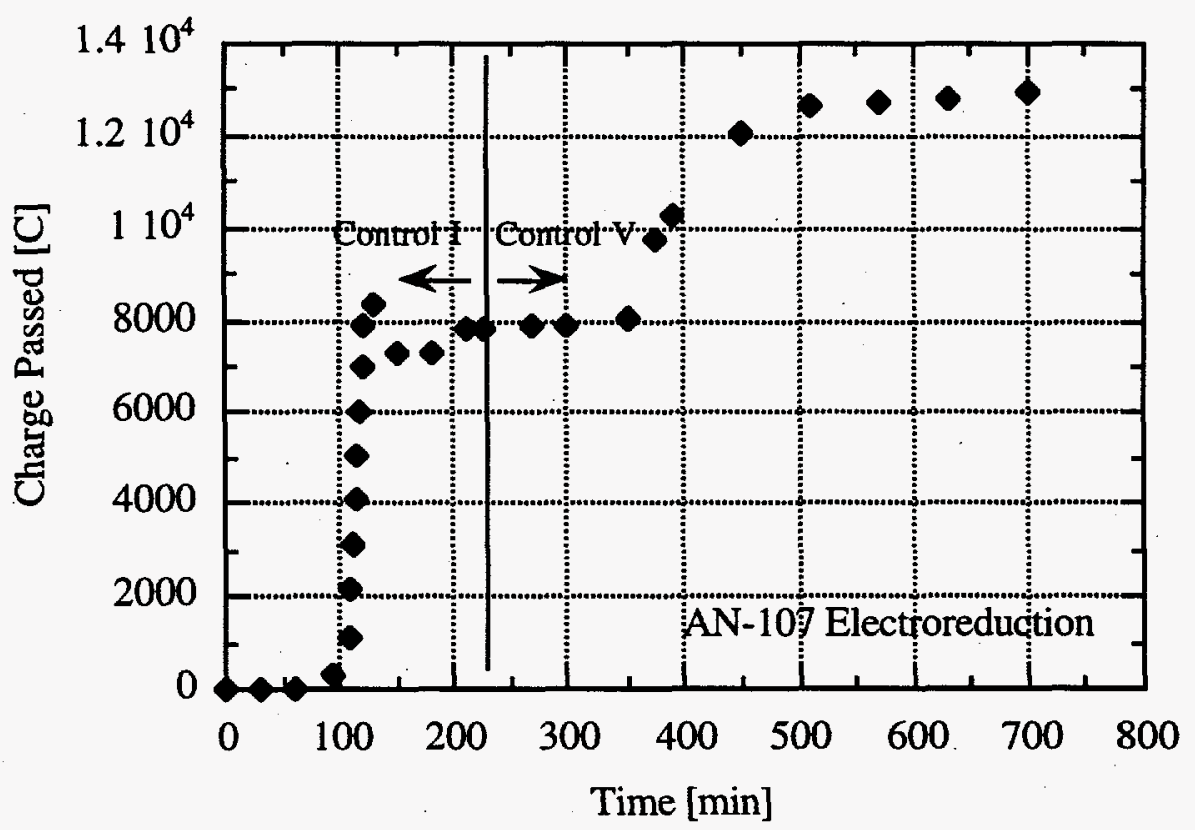

Figure 3.16. Charge Passed Versus Time During Electroreduction of AN-107 Waste 


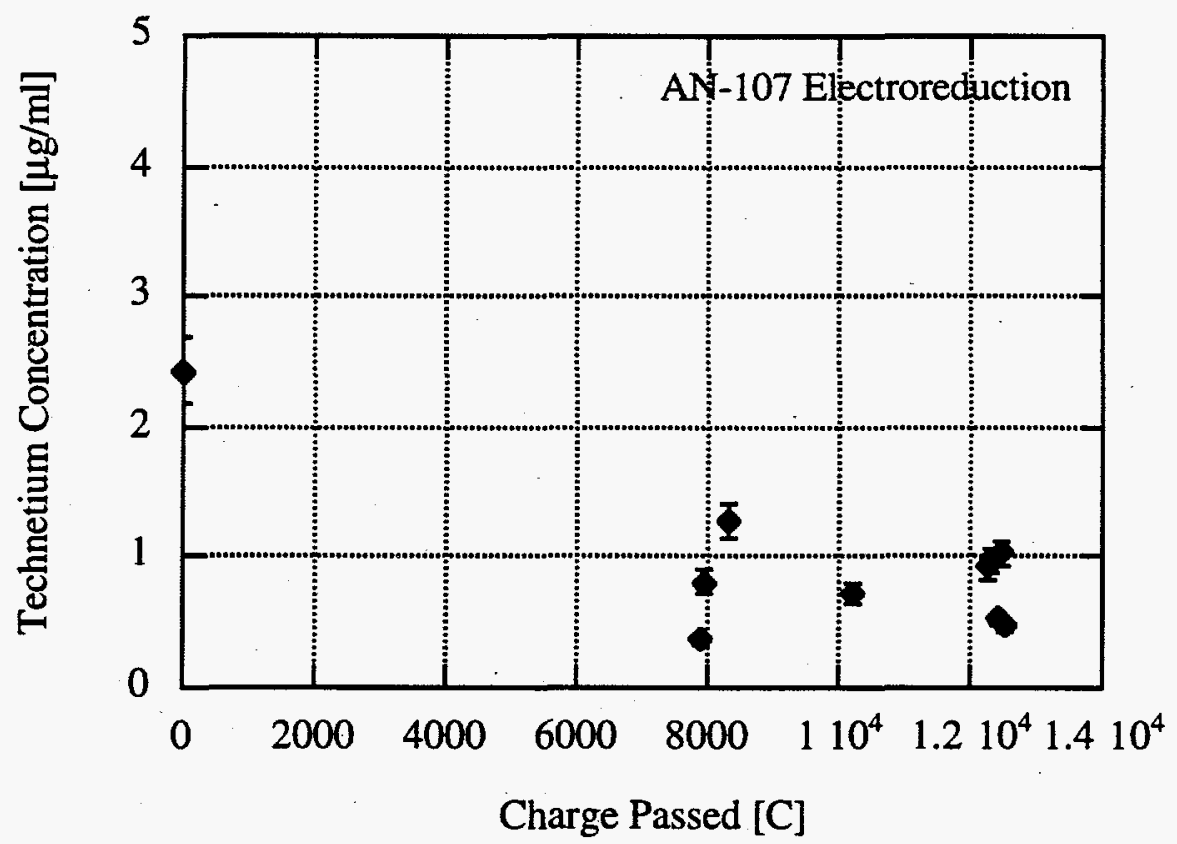

Figure 3.17. ${ }^{99} \mathrm{Tc}$ Concentration Versus Charge Passed During Electroreduction of AN-107 Feed

Between 8000 and $1 \times 10^{4} \mathrm{C}$ the increase in $99 \mathrm{Tc}$ concentration is due to the application of an anodic current and the fact that no potential bias was applied for some time before the potential step operation. After $1 \times 10^{4} \mathrm{C}$, it appears that the ${ }^{99} \mathrm{Tc}$ deposit is undergoing a dissolution or delamination followed by a redeposition. It is not known whether this variability in the $99 \mathrm{Tc}$ concentration is related to the high organic content or to interference from other species such as chrome compounds. The variability in the concentration does not significantly influence the DF, as shown in Figure 3.18.

The DF is plotted against the charge passed in Figure 3.18. The DF reaches a high of 6.7 during the constant current operation. During the potential step operation, the final sample showed a DF of approximately 5 , although the values varied from around 2.5 to 5 and averaged about 3.5 . This is slightly below the anticipated removal requirement of 5 . It should be noted that a DF $>5$ was obtained under constant current operation. Approximately $8000 \mathrm{C}$ were passed over an operating period of 30 minutes compared to $5000 \mathrm{C}$ for the electroreduction over eight hours. Also, the final DFs are increasing, indicating that higher DFs may be achievable with additional processing.

Table 3.2 summarizes the DFs obtained for the simulants by AEAT and for actual wastes in this study. The experimental procedure developed by AEAT on simulant supernatant liquid was adopted by PNNL for the actual waste studies. These results show that the simulant studies overestimated the DF in AW-101 supernatant liquid but are closer in estimates of AN-107 waste. In both simulant and actual waste studies, the high-organic AN-107 supernatant liquid showed much lower DF than that obtained for the AW-101 supernatant liquid. It is not known whether this is because of the organic content only or competition between other electroactive species. The 


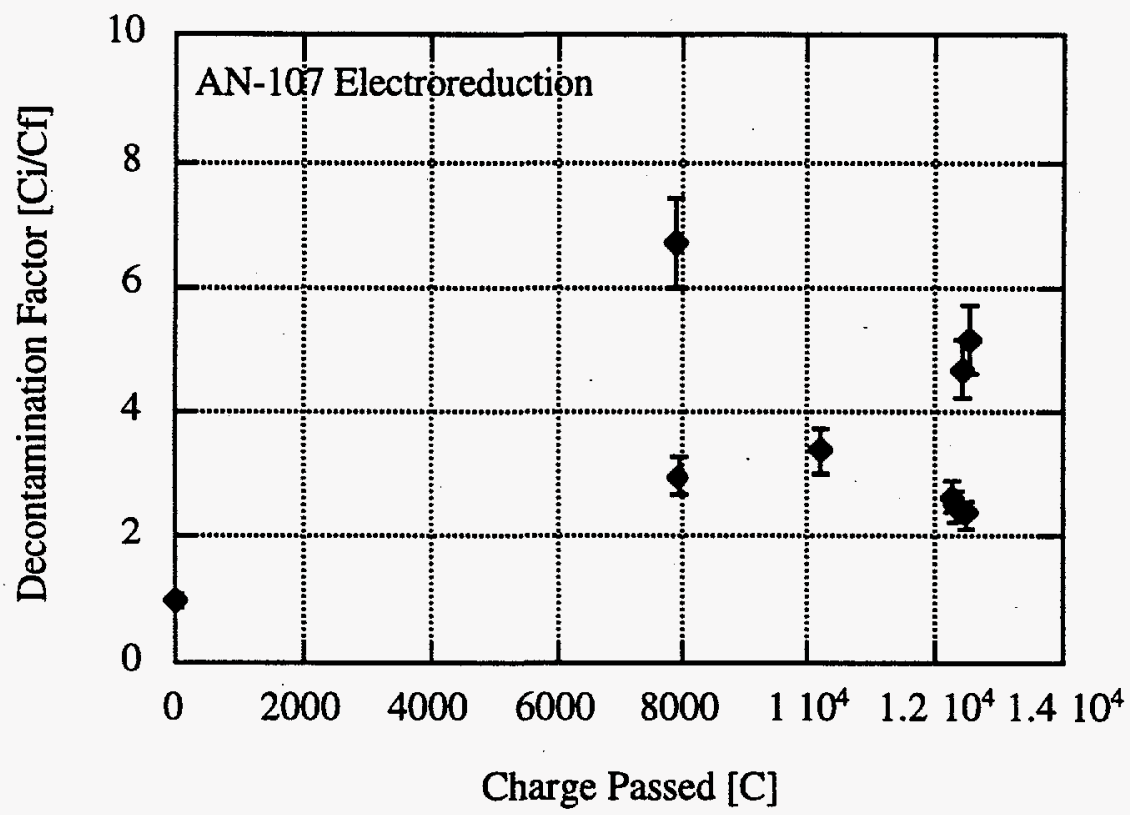

Figure 3.18. ${ }^{99} \mathrm{Tc}$ DF Versus Charge Passed During Electroreduction of AN-107 Waste

DF obtained for the AW-101 exceeds the anticipated target removal of 5; however, the results are not conclusive as to whether the target DF could be consistently achieved for $\mathrm{AN}-107$ high-organic type supernatant liquids. These results indicate that further simulant development is required to more accurately predict the ${ }^{99} \mathrm{Tc}$ removal extents. The nonpertechnetate species present in the actual tank waste supernatant liquids have not been characterized and have only been speculated upon; therefore, significant difficulties exist in developing better simulants. The simulant studies serve as a predictor of the general removal performance, though the accuracy of the removal amount requires validation by actual waste testing.

Table 3.2. Comparison of Simulant and Actual Waste ${ }^{99} \mathrm{Tc}$ Decontamination Factors

\begin{tabular}{|l|c|c|c|}
\hline Performed by & $\begin{array}{c}\text { Tank Waste } \\
\text { Supernatant Liquid }\end{array}$ & $\begin{array}{c}\text { Initial }{ }^{99} \mathrm{Tc} \text { Concentration } \\
(\mu \mathrm{g} / \mathrm{mL})\end{array}$ & DF Obtained \\
\hline AEAT & AW-101 simulant & 8.6 & $>200$ \\
\hline PNNL & AW-101 & 2.8 & 19 \\
\hline AEAT & AN-107 simulant & 1.6 & 17 \\
\hline PNNL & AN-107 & 2.4 & $3-6$ \\
\hline
\end{tabular}


One month after the completion of testing, the lead cathodes were contacted with an acid solution to measure the amount of $99 \mathrm{Tc}$ remaining on the cathodes. Two nitric acid solutions, $0.5 \underline{\mathrm{M}}$ and $1 \underline{\mathrm{M}}$, were in contact with the electrodes for 15 minutes by pumping the solutions through the electrochemical cell. The first contact removed about $120 \mu \mathrm{g}$ of ${ }^{99} \mathrm{Tc}$ and the second about $15 \mu \mathrm{g}$ for a total of $135 \mu \mathrm{g}$. This is about $10 \%$ of the $99 \mathrm{Tc}$ deposited, indicating that the remaining $90 \%$ of the ${ }^{99} \mathrm{Tc}$ can be removed through rinsing and circulating solutions when no potential bias is applied. The observation of ${ }^{99} \mathrm{Tc}$ dissolution in the absence of a potential bias is in agreement with the results obtained for the constant current reduction in Test 5 . Therefore, to minimize the dissolution of ${ }^{99} \mathrm{Tc}$, a potential bias needs to be maintained, and physical erosion at the electrodes should be minimized. 


\subsection{Conclusions}

This study has demonstrated the ability of electrochemical processing to remove ${ }^{99} \mathrm{Tc}$ from Hanford tank waste supernatant liquids. A procedure developed by AEAT was adopted by PNNL for actual waste testing. AEAT simulant testing indicated that electrochemical oxidation is necessary to reduce the overall TOC content prior to electroreduction. Actual waste testing showed good ${ }^{99} \mathrm{Tc}$ removals for $\mathrm{AW}-101$ supernatant liquid and lower decontamination factors for the $\mathrm{AN}-107$ supernatant liquid. The AW-101 DF exceeds the anticipated removal requirement. The AN-107 DF obtained was at or below the anticipated removal requirement, but the TOC concentration was higher than expected. This suggests that the DF achieved will increase at lower organic concentrations.

The preoxidation of the tank waste supernatant liquids resulted in a decrease in the nonextractable $99 \mathrm{Tc}$. The oxidation of organic species resulted in the partial decomplexation of species such as $90 \mathrm{Sr}$. During two of the three preoxidation tests the TOC was significantly reduced. In the third test minimal TOC destruction was observed, and without further validation the factors can only be speculated upon. Differences in operating potential, temperature, and the waste nonhomogeneity may be contributing factors. The second batch of AN-107 waste feed had a higher sodium content and higher initial TOC content. The supernatant liquid was a darker and denser solution than the first batch. This inhomogeneity in the waste warrants further consideration. Additional verification is recommended to evaluate the effects of waste nonhomogeneity on the removal of ${ }^{99} \mathrm{Tc}$.

The demonstration of ${ }^{99} \mathrm{Tc}$ removal from actual waste indicates that other process operating procedures such as the constant current reduction may prove more efficient than a potential step reduction. The short-term constant current operation provided DFs exceeding that obtained for the longer potential step reduction. Further consideration of constant current reduction operation is recommended because it may serve to significantly reduce operation times. Reduced operation times enable more waste to be treated per unit time or allow a reduction in size of process equipment.

The information obtained in this study was used to support a comparison of electrochemical processing and ion exchange removal of ${ }^{99} \mathrm{Tc}$. The oxidation of nonextractable $99 \mathrm{Tc}$ may prove valuable for comparison to other oxidation methods. Electrochemical processing offers flexibility because it has shown successful ${ }^{99} \mathrm{Tc}$ removal as well as the ability to enhance the ion exchange removal by oxidizing the nonextractable ${ }^{99} \mathrm{Tc}$ and the organics present. 


\subsection{References}

Blanchard DL Jr, GN Brown, SD Conradson, SK Fadeff, GR Golcar, NJ Hess, GS Klinger, and DE Kurath. 1997. Technetium in Alkaline, High-Salt, Radioactive Tank Waste Supernate:

Preliminary Characterization and Removal. PNNL-11386, Pacific Northwest National Laboratory, Richland, Washington.

Elmore MR and WE Lawrence. 1996. Electrochemical Destruction of Organics and Nitrates in Simulated and Actual Radioactive Hanford Tank Waste. PNNL-11590, Pacific Northwest National Laboratory, Richland, Washington.

Hendrickson DW. 1997. Hanford Complexant Concentrate Cesium Removal Using Crystalline Silicotitanate. SESC-EN-RPT-005, SGN Eurisys Services Corporation, Richland, Washington.

Hobbs DT. 1992. "Electrochemical Treatment of Nuclear Waste at the Savannah River Site." Chapter 12 in Electrochemistry for a Cleaner Environment, JD Genders and NL Weinberg, eds. Electrosynthesis Company Inc., East Amherst, New York.

Orme RM, AF Mauel, LW Shelton, and EJ Slaathaug. 1996. Tank Waste Remediation System Privatization Process Technical Baseline. WHC-SD-WM-TI-774, Westinghouse Hanford Company, Richland, Washington.

Pletcher D and FC Walsh. 1993. Industrial Electrochemistry. Blackie Academic and Professional, an imprint of Chapman \& Hall, London.

Van Vleet RJ. 1993. Radionuclide and Chemical Inventories for the Double Shell Tanks. WHC-SD-WM-TI-543 Rev. 1, Westinghouse Hanford Company, Richland, Washington.

Walsh FC. 1993. A First Course in Electrochemical Engineering. The Electrochemical Consultancy, Hants, England. 


\section{Distribution}

No. Of

Copies

\section{Offsite}

2 Office of Scientific and Technical Information

Phil McGinnis

PO Box 2008

Bethel Valley Rd $4500 \mathrm{~N}$

Rm B-16

Oak Ridge, Tennessee 37831

Dr. David Hobbs

Westinghouse Savannah River Co.

Savannah River Technology Center

Building 773-A

Room B-117

Aiken, South Carolina 29802

Dr: Chris Jones

AEA Technology Plc.

Harwell

Didcot

Oxfordshire OX11 ORA

United Kingdom

Dr. Pat Fletcher

AEA Technology Plc.

Harwell

Didcot

Oxfordshire OX11 ORA

United Kingdom
No. Of

Copies

Onsite

18 Pacific Northwest National Laboratory

S. Q. Bennett

K7-90

W. E. Lawrence (8)

P7-41

D. L. Blanchard (3)

P7-25

D. E. Kurath

P7-28

Information Release Office (5) 